\title{
Fate and effect of allochthonous organic material in aquatic microbial ecosystems. An analysis based on chemostat theory
}

\author{
T. F. Thingstad and B. Pengerud
}

Department of Microbiology and Plant Physiology, Allégt. 70, University of Bergen, Norway

\begin{abstract}
Two mathematical descriptions of a microbial ecosystem with external input of organic material were formulated. Included in these descriptions are only those parts of the ecosystem which are thought to be of key importance in the linkage between flows of organic material and mineral nutrients. The simplest model, based upon Monod-kinetics of growth and constant cell composition, is amenable to graphical analysis. It was used to explore 2 complementary aspects: How does organic load alter the equilibirum state of the ecosystem, and how do the mechanisms of mineral cycling between bacteria, algae and protozoans influence degradation of the organic material? The other model is based on an extension of Droop's model for algal growth which allows for variations in cell composition. By simulation techniques, the effects of this refinement were explored.
\end{abstract}

\section{INTRODUCTION}

In a recent paper, Azam et al. (1983) introduced the term 'microbial loop' for that part of the microbial ecosystem which transports organic material via bacteria into the food chain. They stated .... it should be evident that carbon and mineral flows in the 'microbial loop' are tightly coupled. Information on the nature of this coupling is thus essential for an understanding of the dynamic behaviour of the 'microbial loop'. Since many marine pollution situations include the addition of mineral nutrients and/or organic carbon to the ecosystem, an understanding of the regulating mechanisms within the 'microbial loop' is important ( $p$. 261). This kind of ecological system is highly interactive and dynamic, and it is difficult to see how a deeper insight into the composite functioning of the 'microbial loop' could be gained without the use of some kind of mathematical systems' theory. The work presented here is an attempt to construct a meaningful mathematical model of the 'microbial loop', simple enough to explore the consequences of some of the many interacting mechanisms.

The important role of bacteria as degraders of organic material is generally accepted. As to the linkage between this flux of organic material and the accompanying flux of mineral nutrients, however, no unified consensus has yet been established. Neither the magnitude nor even the general direction of this mineral flux is known in marine ecosystems. The suggestion advanced by Johannes (1968), that bacteria may be more important as consumers than as remineralizers of mineral nutrients in aquatic environments, is advocated in a recent textbook discussing this subject (e.g. Mann, 1982).

If an organic carbon compound without $N$ or $P$ is added externally to a system where phytoplankton

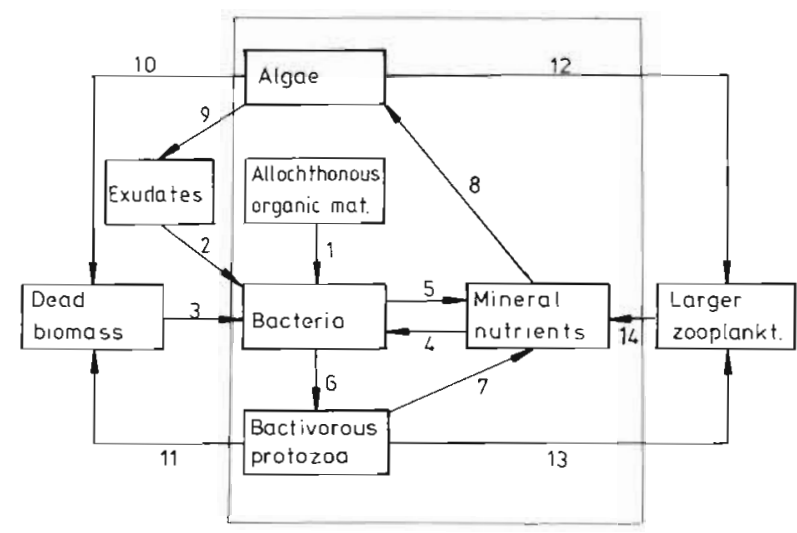

Fig. 1. Schematic model of components and processes assumed to be closely linked to the bacterial degradation of allochthonous organic matter. Numbers refer to discussion in text. Frame marks the part of the system analyzed in this paper 
growth is already limited by low availability of mineral nutrients, this coupling should become especially prominent. In such a case bacteria must satisfy their requirement for $\mathrm{N}$ and $\mathrm{P}$ through uptake of dissolved minerals (Fenchel and Blackburn, 1979), in competition with the phytoplankton. An example of such an externally supplied carbon source could be oil pollution, the degradation of which may be limited in environments low in mineral nutrients (Atlas, 1981). Fig. 1 gives a schematic picture of those components of the planktonic microbial ecosystem presumably most closely linked to the degradation process. Important parts of this picture are: The bacterial degradation of externally supplied organic material (1) (numbers refer to Fig. 1) or autochthonous material such as algal exudates (2) and dead biomass (3). Depending upon the ratio of carbon to mineral nutrients in the substrate, mineral nutrients may be assumed either to be consumed (4) or excreted (5) by the bacteria. Mineral nutrients may also be removed by algal uptake (8) or produced by excretion from bacterial predators such as bactivorous microflagellates (7) and from larger zooplankton (14). As suggested in Fig. 1, the process of bacterial degradation of externally supplied carbon

Table 1. State variables of the 2 models

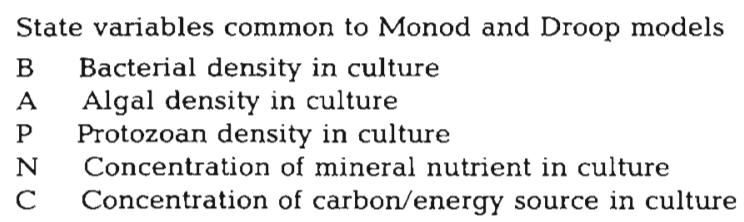

State variables common to Monod and Droop models

B Bacterial density in culture

A Algal density in culture

$\mathrm{P}$ Protozoan density in culture

$\mathrm{N}$ Concentration of mineral nutrient in culture

C Concentration of carbon/energy source in culture

State variables specific for Droop model

$\mathrm{B}_{\mathrm{C}}$ Carbon in bacterial biomass

$B_{N} \quad$ Mineral nutrient in bacterial biomass

$A_{N}$ Mineral nutrient in algal biomass

From which are computed for Droop model:

$\mathrm{Q}_{\mathrm{BC}}=\mathrm{B}_{\mathrm{C}} / \mathrm{B} \quad$ Bacterial cell quota, carbon

$\mathrm{Q}_{\mathrm{BN}}=\mathrm{B}_{\mathrm{N}} / \mathrm{B} \quad$ Bacterial cell quota, mineral nutrient

$Q_{\mathrm{AN}}=A_{N} / A \quad$ Algal cell quota, mineral nutrient

The above symbols are given superscript " to denote equilibrium values and subscripts B, BA or BAP to denote situations with bacteria alone, bacteria and algae or bacteria, algae and protozoans, respectively

Table 2. Environmental parameters used in Monod and Droop models with numerical values used in simulation of Droop model
D Dilution rate
$\mathrm{N}_{\mathrm{i}} \quad$ Concentration of mineral nutrient in reservoir
$\mathrm{C}_{\mathrm{i}} \quad$ Concentration of carbon source in reservoir. Eight different values used in simulation

\begin{tabular}{|c|c|c|c|}
\hline \multicolumn{4}{|c|}{$0.02 \mathrm{~h}^{-1}$} \\
\hline \multicolumn{4}{|c|}{$10 \mu \mathrm{M} \mathrm{PO}_{4}$ in all chemostats } \\
\hline .168 & .336 & .843 & 1.67 \\
\hline 2.50 & 3.34 & 5.00 & 6.72 \\
\hline
\end{tabular}

Table 3. Biological parameters of Monod model

\begin{tabular}{|c|c|}
\hline$\mu_{B}^{\max }$ & Max. specific growth rate, bacteria \\
\hline$\mu_{\mathrm{A}}^{\max }$ & Max. specific growth rate, algae \\
\hline $\mathrm{p}^{\max }$ & Max. specific predation rate, protozoans \\
\hline $\mathrm{K}_{\mathrm{BC}}$ & $\begin{array}{l}\text { Half saturation constant, bacterial growth on } \\
\text { carbon source }\end{array}$ \\
\hline $\mathrm{K}_{\mathrm{BN}}$ & $\begin{array}{l}\text { Half saturation constant, bacterial growth on } \\
\text { mineral nutrient }\end{array}$ \\
\hline $\mathrm{K}_{\mathrm{AN}}$ & $\begin{array}{l}\text { Half saturation constant, algal growth on } \\
\text { mineral nutrient }\end{array}$ \\
\hline $\mathrm{K}_{\mathrm{PB}}$ & $\begin{array}{l}\text { Half saturation constant, protozoan predation } \\
\text { on bacteria }\end{array}$ \\
\hline $\mathrm{Y}_{\mathrm{BC}}$ & Yield of bacteria on carbon source \\
\hline$Y_{B N}$ & Yield of bacteria on mineral nutrient \\
\hline $\mathrm{Y}_{\mathrm{AN}}$ & Yield of algae on mineral nutrient \\
\hline$Y_{P B}$ & Yield of protozoans on bacteria \\
\hline r & $\begin{array}{l}\text { Amount of mineral nutrient regenerated per } \\
\text { bacteria eaten }\end{array}$ \\
\hline
\end{tabular}

would presumably be influenced by the supplies of autochthonous organic bacterial substrates such as phytoplankton excretions (9) or death of planktonic organisms $(10,11)$. The predation pressure from organisms further up the food chain $(12,13)$ would also be of importance since it may directly affect the level and activity of both bacterial competitors and predators, in addition to the effects of remineralization from such zooplankton.

An analysis including these latter effects (9 to 14) would be extensive and complex. By neglecting the processes of internal production of degradable organic matter, as well as the effects of higher predators, models amenable to mathematical analysis are constructed.

Studying glucose degradation in the laboratory with chemostat systems of mixed pure cultures of bacteria, algae and bactivorous microflagellates, we found it rewarding to analyze how simple mathematical mod- 
Table 4. Monod model: equations

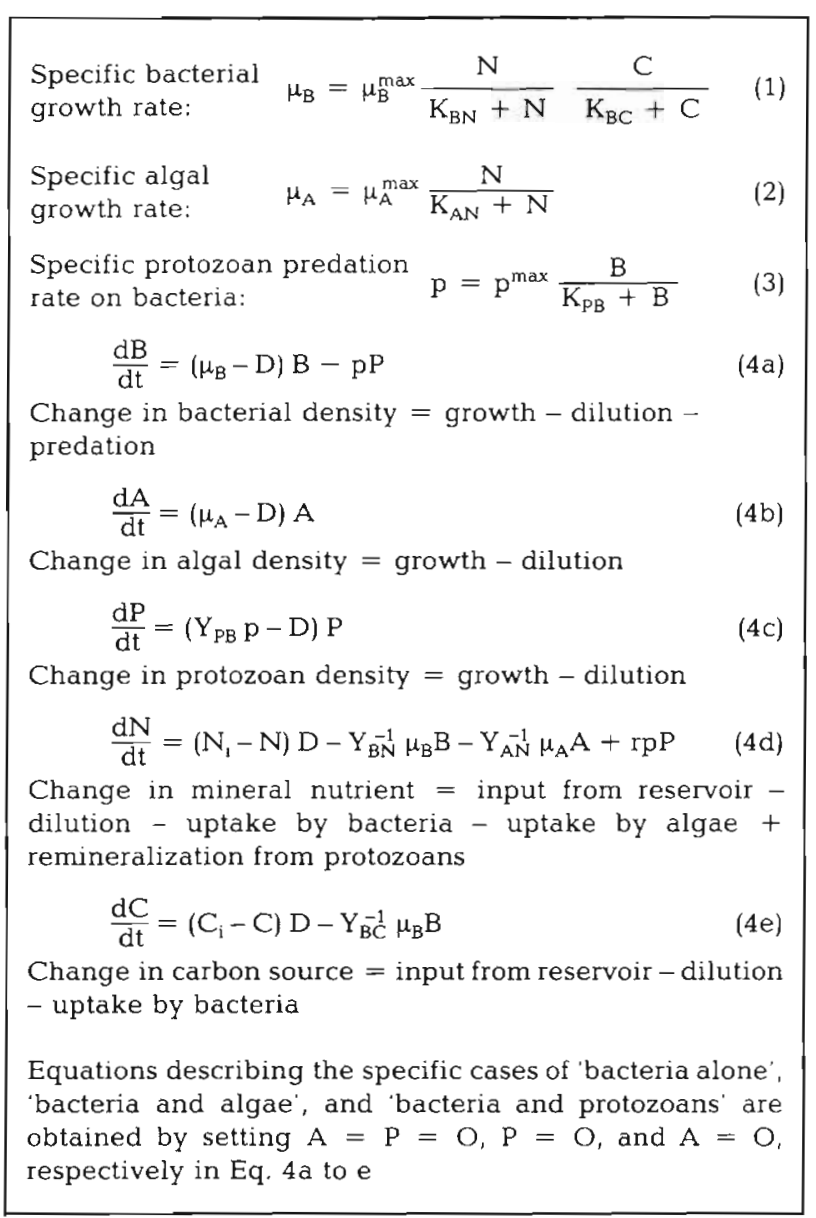

els would predict the outcome of such experiments. For this reason, we have chosen to analyze a set of models of continuous cultures where the input media contain identical concentrations of the potentially limiting mineral nutrient, but different concentrations of organic material. This corresponds to the experimental setup used by Brown et al. (1981) for the study of competition for phosphorus between a cyanobacterium and a yeast. For the mathematical analysis we use a simple model based on Monod kinetics (Monod, 1942) and constant cell yields, allowing graphical analysis of the effects of the population properties on the degradation of organic matter. This model has the serious shortcoming of assuming a constant biomass composition, independent of growth conditions. To include the effects of variable biomass composition, the analytical results of the model based upon Monod kinetics are compared to results of a simulation model based upon an adaptation of Droop's model for algal growth (Droop, 1974). The symbols and equations of both models and the numerical values used in the simulation of the Droop model are summarized in Tables 1 through 7 .

\section{SITUATION 1: BACTERIA ALONE}

\section{Monod kinetics with constant yields}

Classical chemostat theory (Herbert et al., 1956) assumes 1 substrate only to be limiting. Here we need to analyze a system with 2 potentially limiting sub-

Table 5. Droop model: parameters with numerical values used in simulation

\begin{tabular}{|c|c|c|c|}
\hline \multicolumn{4}{|c|}{ Bacteria } \\
\hline$\mu_{B}^{\max }$ & \multicolumn{2}{|c|}{$0.2 \mathrm{~h}^{-1}$} & Maximum specific growth rate, bacteria \\
\hline $\mathrm{R}_{\mathrm{B}}$ & \multicolumn{2}{|c|}{$15 \mu \mathrm{molC}\left(10^{9} \text { cells formed }\right)^{-1}$} & Respiration requirement for bacterial growth \\
\hline$v_{B C}^{\max }$ & \multicolumn{2}{|c|}{$1.0 \mu \mathrm{molC} \mathrm{h} \mathrm{h}^{-1}\left(10^{9} \text { cells }\right)^{-1}$} & Maximum specific uptake velocity of carbon source by bacteria \\
\hline$K_{\mathrm{BC}}$ & \multicolumn{2}{|c|}{$100 \mu \mathrm{molC} \mathrm{l}^{-1}$} & Half saturation constant for bacterial uptake of carbon source \\
\hline$Q_{\mathrm{BC}}^{\min }$ & \multicolumn{2}{|c|}{$10 \mu \mathrm{molC}\left(10^{9} \text { cells }\right)^{-1}$} & Minimum cell quota of carbon in bacteria \\
\hline$v_{B N}^{\max }$ & \multicolumn{2}{|c|}{$0.1 \mu \mathrm{mol} \mathrm{PO}{ }_{4}\left(10^{9} \text { cells }\right)^{-1} \mathrm{~h}^{-1}$} & Maximum specific uptake rate of mineral nutrient, bacteria \\
\hline $\mathrm{K}_{\mathrm{BN}}$ & \multicolumn{2}{|c|}{$0.5 \mu \mathrm{mol} \mathrm{PO} \mathrm{P}^{-1}$} & Half saturation constant for bacterial uptake of mineral nutrient \\
\hline \multicolumn{4}{|c|}{ Algae } \\
\hline$\mu_{A}^{\max }$ & \multicolumn{2}{|c|}{$0.1 \mathrm{~h}^{-1}$} & Maximum specific growth rate, algae \\
\hline$v_{A N}^{\max }$ & \multicolumn{2}{|c|}{$0.1 \mu \mathrm{mol} \mathrm{PO}_{4}\left(10^{7} \text { cells }\right)^{-1} \mathrm{~h}^{-1}$} & Maximum specific uptake rate of mineral nutrient in algae \\
\hline $\mathrm{K}_{\mathrm{AN}}$ & \multicolumn{2}{|c|}{$0.75 \mu \mathrm{mol} \mathrm{PO} \mathrm{P}^{-1}$} & Half saturation constant for uptake of mineral nutrient, algae \\
\hline$Q_{A N}^{\min }$ & \multicolumn{2}{|c|}{$0.1 \mu \mathrm{mol} \mathrm{PO}{ }_{4}\left(10^{7} \text { cells }\right)^{-1}$} & Minimum cell quota of mineral nutrient in algae \\
\hline \multicolumn{4}{|c|}{ Bactivorous protozoans } \\
\hline$p^{\max }$ & 0.05 & $10^{9}$ bact $\left(10^{7} \text { protozoans }\right)^{-1} \mathrm{~h}^{-1}$ & Maximum specific predation rate \\
\hline $\mathrm{K}_{\mathrm{PB}}$ & & $10^{9}$ bact. $1^{-1}$ & Half saturation constant for predation \\
\hline$B^{\operatorname{lnm}}$ & & $10^{9}$ bact. $1^{-1}$ & Lower limit of predation \\
\hline$Q_{P N}$ & & $\mu \mathrm{mol} \mathrm{PO}_{4}\left(10^{7} \text { cells }\right)^{-1}$ & Fixed cell quota of mineral nutrient \\
\hline $\mathrm{R}_{\mathrm{p}}$ & 0.4 & & Fraction of carbon respired \\
\hline $\mathrm{R}_{\mathrm{CN}}$ & 100 & & Carbon: mineral nutrient molar ratio \\
\hline
\end{tabular}


Table 6. Droop model: equations describing biological processes

\begin{tabular}{|c|c|c|}
\hline $\begin{array}{l}\text { Specific uptake rate } \\
\mathrm{v}_{B C} \text { of carbon in bacteria }\end{array}$ & $v_{B C}=v_{B C}^{\max } \frac{Q_{B C}^{\min }}{Q_{B C}} \frac{C}{K_{B C}+C}$ & (5) \\
\hline $\begin{array}{l}\text { Specific uptake rate } \\
v_{B N} \text { of mineral } \\
\text { nutrient in bacteria }\end{array}$ & $v_{B N}=v_{B N}^{\max } \frac{Q_{B N}^{\min }}{Q_{B N}} \frac{N}{K_{B N}+N}$ & (6) \\
\hline $\begin{array}{l}\text { Specific uptake rate } \\
\mathrm{v}_{\text {AN }} \text { of mineral } \\
\text { nutrient in algae }\end{array}$ & $v_{A N}=v_{A N}^{\max } \frac{Q_{A N}^{\min }}{Q_{A N}} \frac{N}{K_{A N}+N}$ & (7) \\
\hline $\begin{array}{l}\text { Specific bacterial } \\
\text { growth rate } \mu_{B}\end{array}$ & $\mu_{\mathrm{B}}=\mu_{\mathrm{B}}^{\max }\left(1-\frac{Q_{\mathrm{BN}}^{\min }}{Q_{\mathrm{BN}}}\right)\left(1-\frac{Q_{\mathrm{BC}}^{\min }}{Q_{\mathrm{BC}}}\right)$ & (8) \\
\hline $\begin{array}{l}\text { Specific algal growth } \\
\text { rate } \mu_{\mathrm{A}}\end{array}$ & $\mu_{\mathrm{A}}=\mu_{\mathrm{A}}^{\max }\left(1-\frac{Q_{\mathrm{AN}}^{\min }}{Q_{\mathrm{AN}}}\right)$ & (9) \\
\hline \multirow[t]{2}{*}{$\begin{array}{l}\text { Total predation } \\
\text { rate } P_{R}\end{array}$} & $P_{R}=P^{\max } \frac{B-B^{\lim }}{K_{P B}+\left(B-B^{1 / \mathrm{m}}\right)} P$ & $(10 a)$ \\
\hline & $\begin{array}{l}\text { if } \mathrm{B}>\mathrm{B}^{\mathrm{lim}} \\
\mathrm{P}_{\mathrm{R}}=0 \text { if } \mathrm{B}<\mathrm{B}^{\lim }\end{array}$ & (10b) \\
\hline $\begin{array}{l}\text { Carbon content } P_{B C} \\
\text { of bacteria eaten }\end{array}$ & $P_{B C}=Q_{B C} P_{R}$ & (11a) \\
\hline $\begin{array}{l}\text { Mineral nutrient } \\
\text { content } P_{B N} \text { of } \\
\text { bacteria eaten }\end{array}$ & $P_{B N}=Q_{B N} P_{R}$ & $(11 b)$ \\
\hline $\begin{array}{l}\text { Potential predator } \\
\text { biomass carbon } \mathrm{P}_{\mathrm{PC}} \\
\text { which may be } \\
\text { formed on } \mathrm{P}_{\mathrm{BC}}\end{array}$ & $P_{P C}=P_{B C}\left(1-R_{P}\right)$ & (11c) \\
\hline $\begin{array}{l}\text { Potential predator } \\
\text { biomass carbon } \mathrm{P}_{\mathrm{PN}} \\
\text { which may be formed } \\
\text { on } \mathrm{P}_{\mathrm{BN}}\end{array}$ & $P_{P N}=P_{B N} R_{C N}$ & (11d) \\
\hline \multirow[t]{4}{*}{$\begin{array}{l}\text { Production of proto- } \\
\text { zoans } P_{\mathrm{PROD}} \text { and } \\
\text { excretion } \mathrm{N}_{\mathrm{ExC}} \text { of sur- } \\
\text { plus mineral nutrient }\end{array}$} & $P_{\mathrm{PROD}}=Q_{\mathrm{PN}}^{-1} P_{\mathrm{PN}}$ & $(11 \mathrm{e})$ \\
\hline & $N_{E X C}=0.0$ if $P_{P C} \geqq P_{P N}$ & $(11 \mathrm{f})$ \\
\hline & $P_{P R O D}=P_{P C} R_{C N}^{-1} Q_{P N}^{-1}$ & $(11 \mathrm{~g})$ \\
\hline & $N_{E X C}=P_{P N}-P_{P C} Q_{P N}^{-1}$ & (11h) \\
\hline
\end{tabular}

strates for bacterial growth. This situation was discussed by Bader et al. (1975) who pointed out the 2 different theoretical approaches to this problem: interactive or noninteractive growth on the 2 substrates. An analysis corresponding to Bader's interactive Monod model is given here in some detail to provide the conceptual framework for the subsequent analysis of competition and predation situations. A discussion of the consequences of a noninteractive model is included later in this paper.

As seen from Equation 1 (Table 4) we have chosen a mathematical form where specific bacterial growth rate is assumed to be a product of 2 Monod terms,
Table 7. Droop model: differential equations

$$
\frac{\mathrm{dB}_{\mathrm{C}}}{\mathrm{dt}}=\mathrm{v}_{\mathrm{BC}} \mathrm{B}-\mathrm{R}_{\mathrm{B}} \mu_{\mathrm{B}} \mathrm{B}-\mathrm{B}_{\mathrm{C}} \mathrm{D}-\mathrm{P}_{\mathrm{BC}}
$$

Change in bacterial carbon = uptake - respiration dilution - predation

$$
\frac{\mathrm{dB}_{\mathrm{N}}}{\mathrm{dt}}=\mathrm{v}_{\mathrm{BN}} \mathrm{B}-\mathrm{B}_{\mathrm{N}} \mathrm{D}-\mathrm{P}_{\mathrm{BN}}
$$

Change in bacterial mineral nutrient $=$ uptake dilution - predation

$$
\frac{\mathrm{dB}}{\mathrm{dt}}=\left(\mu_{\mathrm{B}}-\mathrm{D}\right) \mathrm{B}-\mathrm{P}_{\mathrm{R}}
$$

Change in bacterial density $=$ growth - dilution predation

$$
\frac{d A_{N}}{d t}=v_{A N} A-D A_{N}
$$

Change in algal mineral nutrient $=$ uptake - dilution

$$
\frac{\mathrm{dA}}{\mathrm{dt}}\left(\mu_{\mathrm{A}}-\mathrm{D}\right) \mathrm{A}
$$

Change in algal density $=$ growth - dilution

$$
\frac{\mathrm{dP}}{\mathrm{dt}}=\mathrm{P}_{\mathrm{PROD}}-\mathrm{DP}
$$

Change in protozoans $=$ production - dilution

$$
\frac{\mathrm{dN}}{\mathrm{dt}}=\left(\mathrm{N}_{\mathrm{i}}-\mathrm{N}\right) \mathrm{D}-\mathrm{v}_{\mathrm{BN}} \mathrm{B}-\mathrm{v}_{\mathrm{AN}} \mathrm{A}+\mathrm{N}_{\mathrm{ExC}}
$$

Change in free mineral nutrient $=$ input from reservoir - dilution - uptake by bacteria - uptake by algae + remineralization from protozoans

$$
\frac{d C}{d t}=\left(C_{i}-C\right) D-v_{B C} B
$$

Change in free carbon source $=$ input from reservoir - dilution - uptake by bacteria

making both mineral nutrient $\mathrm{N}$ and carbon source $\mathrm{C}$ necessary for bacterial growth, and leading to interactive growth. An expression of this kind was used by Megee et al. (1972). At equilibrium $(\mathrm{dB} / \mathrm{dt}=\mathrm{dN} / \mathrm{dt}=$ $\mathrm{dC} / \mathrm{dt}=\mathrm{O} ; \mathrm{A}=\mathrm{P}=\mathrm{O}$ ), Equation $4 \mathrm{a}$ (Table 4) gives:

$$
\mu_{\mathrm{B}}(\mathrm{N}, \mathrm{C})=\mathrm{D}
$$

The $\mu_{B}(N, C)$-function is a curved surface above the $\mathrm{C}, \mathrm{N}$-plane being zero along the $\mathrm{C}$ and $\mathrm{N}$ axes and giving Monod functions when cut parallel to the $Z-C$ or Z-N planes (Fig. 2a). Equation 13 describes the projection into the $\mathrm{C}, \mathrm{N}$-plane of the cut between this surface and the horizontal plane $\mathrm{Z}=\mathrm{D}$ (Fig. 2a). This gives a hyperbola in the $C_{1} N$-plane with an increasing distance from the origin with increasing $\mathrm{D}$ as shown in Fig. 2b. Combination of Eq. $4 \mathrm{~d}$ and $4 \mathrm{e}$ (Table 4) at equilibrium in this 'bacteria alone' situation gives:

$$
\mathrm{Y}_{\mathrm{BC}}\left(\mathrm{C}_{\mathrm{t}}-\mathrm{C}\right)=\mathrm{Y}_{\mathrm{BN}}\left(\mathrm{N}_{\mathrm{i}}-\mathrm{N}\right)
$$

describing the fact that the amount of bacteria formed on the amount of carbon substrate removed, must equal the amount of bacteria formed on the amount of mineral nutrient removed. Or identically: the propor- 

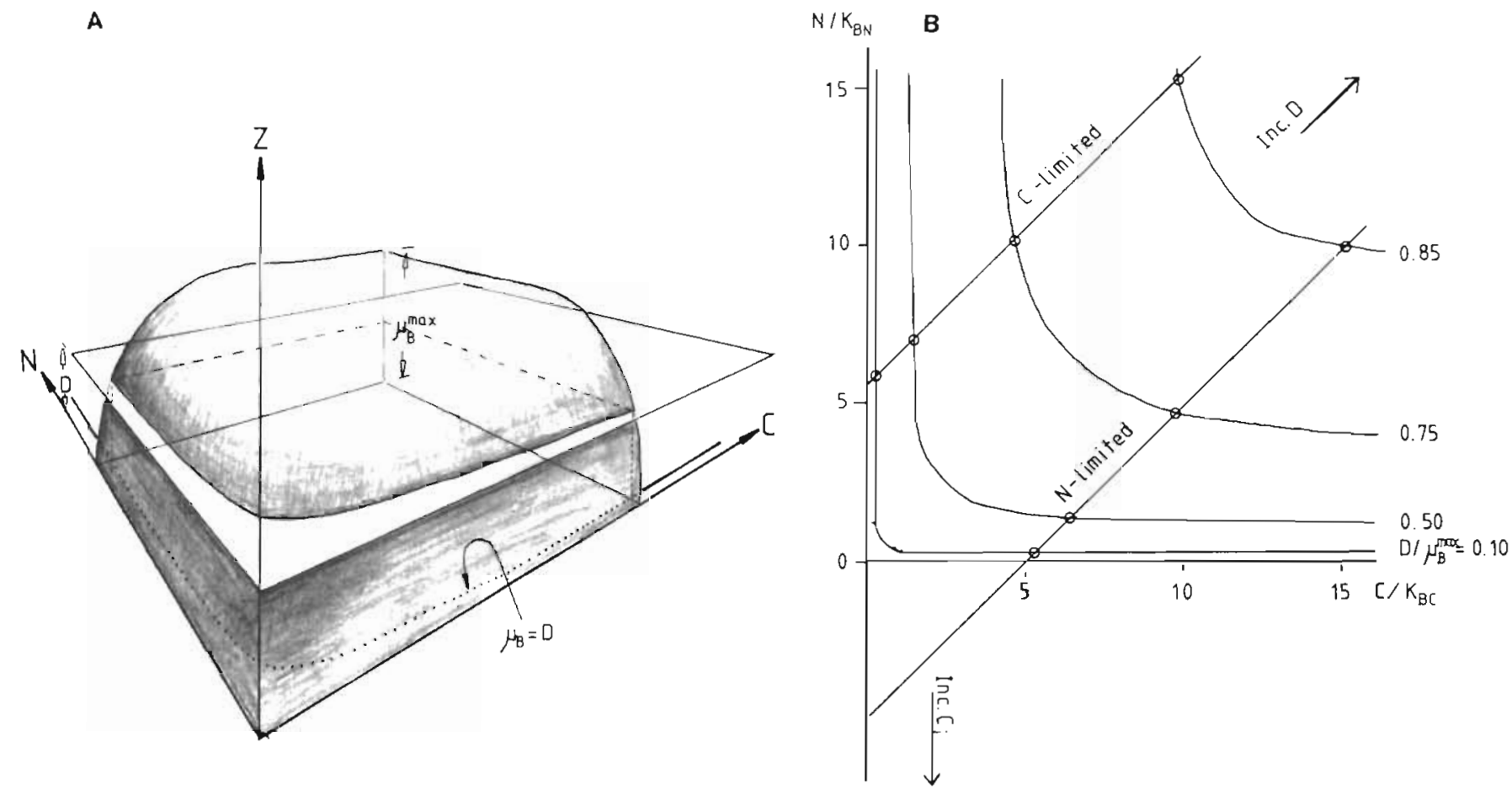

Fig. 2. Monod-model, 'bacteria alone'. (A) Visualization of the curved surface $Z=\mu_{B}(N, C)$ and the horizontal plane $Z=D$. Projection of the cut between these into the $\mathrm{C}, \mathrm{N}$-plane gives a hyperbola along which $\mu_{\mathrm{B}}=\mathrm{D}$, i.e. where the bacterial density is at equilibrium. (B) Culture equilibrium values for mineral and organic nutrient, respectively. These are found at the points (marked with circles) where the hyperbola $\mu_{B}=D$ intersects the line $Y_{B C}\left(C_{1}-C\right)=y_{B N}\left(N_{i}-N\right)$. For a given organism (i.e. a given set of $\mu_{B}^{\text {max }}$, $\mathrm{K}_{\mathrm{BC}}$ and $\mathrm{K}_{\mathrm{BN}}$-values), and a given set of environmental conditions ( $\mathrm{D}, \mathrm{C}_{1}$ and $\mathrm{N}_{1}$ ), one and only one solution is found. Increasing $\mathrm{D}$ moves the hyperbola outwards and increasing $C_{1}$ moves the line downwards. Figure based upon the dimensionless quantities $\mathrm{C} / \mathrm{K}_{\mathrm{BC}}, \mathrm{N} / \mathrm{K}_{\mathrm{BN}}$, and $\mathrm{D} / \mu_{\mathrm{B}}^{\max }$

tion between the amounts removed of the 2 substrates must equal the proportion at which they are consumed by the bacterial population. Eq. 14 gives a straight line in the C,N-plane (Fig. 2b). Since both Eq. 13 and 14 must be fulfilled simultaneously, the equilibrium $C_{B}$, $\mathrm{N}_{\mathrm{B}}$ (Superscript used to denote equilibrium values, Subscript B to denote 'bacteria alone' situation), is given at the intersection between the hyperbola and the straight line in Fig. $2 \mathrm{~b}$. The variation in this picture with varying chemostat conditions is quite simple to analyze since the position of the hyperbola moves with changing dilution rate $D$, but is independent of the reservoir substrate concentrations $C_{1}$ and $N_{i}$. The straight line (Eq. 14) is, however, independent of $D$, but moves downwards with increasing $C_{i}$. In Fig. $2 b$, the transition between limitation on organic and on mineral nutrient occurs as the intersection between the straight line and the hyperbola moves from the vertical to the horizontal leg of the hyperbola. The consequences for our hypothetical experimental situation with varying $C_{i}$, but constant $N_{1}$, is shown in Fig. 3 . As $C_{i}$ is increased, equilibrium $N$ decreases and bacterial density increases until the point $C_{10}=\left(Y_{B N} / Y_{B C}\right) N_{i}$ is reached. Increasing the concentration of organic input beyond this point will, due to limitation on mineral nutrient, not increase the bacterial density. Excess organic material appears in the culture as undegraded material. As can be seen from Fig. $2 b$ the transition between the 2 states becomes more and more gradual as $D$ increases and the bending of the $\mu_{B}=D$ curve becomes less and less sharp. The effect is indicated by dotted lines in Fig. 3. Details of this effect are of course dependent upon the exact form of the $\mu_{B}$-function for low values of $\mathrm{C}$ and $\mathrm{N}$ (Eq. 1; Table 4).

\section{An adaption of the Droop model to bacterial growth}

The Monod model with constant cellular yields is easily amenable to graphical analysis as demonstrated above. It is well known, however, that bacteria may store both mineral nutrients such as polyphosphates and organic reserve materials such as poly- $\beta$-hydroxybutyrate (Dawes and Senior, 1973) under special growth conditions. The respiration of organic material may also vary with growth conditions (Pirt, 1982). These phenomena will have a profound effect on the ratio between the amounts of organic and mineral nutrient consumed.

As a simple mathematical description suitable to 


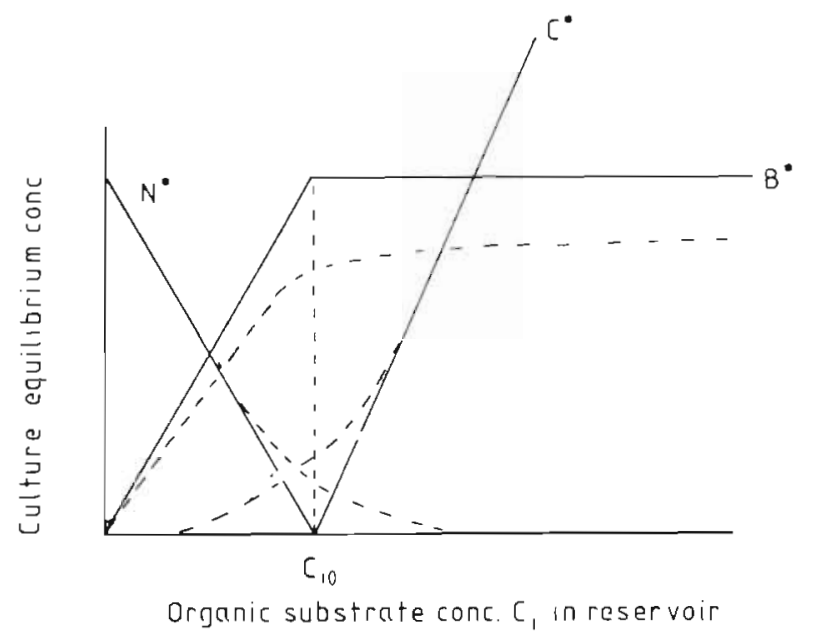

Fig. 3. Monod model, 'bacteria alone'. Effect of increasing organic substrate concentration in reservoir $\left(C_{l}\right)$ on culture equilibrium values for bacteria $\left(B^{*}\right)$, organic substrate $\left(C^{*}\right)$ and mineral nutrient $\left(\mathrm{N}^{*}\right)$ in chemostats with bacteria only Dotted lines indicate equilibrium at values of $D$ close to $\mu_{\mathrm{B}}^{\max }$ Transition from limitation on organic substrate to limitation on mineral nutrient at input concentration $\mathrm{C}_{\mathrm{i} 0}$ of organic substrate

account for variable biomass composition with varying growth conditions, we have adapted the model proposed by Droop for algal growth (1974) to bacterial growth on 2 simultaneously required substrates. The expression is given in Eq. 8 (Table 6) and contains the product of 2 terms, one of which will be zero if the internal cell quota of either carbon or mineral nutrient is at the minimum level. The formulation expresses the basic assumption that growth is dependent upon internal, not external nutrient, and that internal supplies of both substrates are required for bacterial growth. For the growth of the alga Monochrysis lutheri on phosphate and vitamin $B_{12}$, Droop (1974) found an assumption of 1 substrate only to be limiting at any one time (non-interactive growth) to be more satisfactory than the interactive model of Eq. 8.

In both bacteria and algae, a decreased internal cell concentration (cell quota) of limiting conservative (in the sense used by Nyholm, 1976) substrates is often observed at low dilution rates in the chemostat. Bacteriologists usually describe this as a variation in yield with varying growth rates (e. g. Tempest et al., 1966), while algal physiologists usually describe the phenomenon as growth rate dependence on cell quota (e. g. Rhee, 1980). On the basis of steady-state chemostat data, these 2 differing views concerning cause and effect cannot be distinguished. Nyholm (1976) examined the available data on bacterial growth and concluded that a linear relation between cell quota, as mg (mg dry wt) $)^{-1}$, and growth rate seemed more appropriate than a hyperbolic relation as in the Droop model.
In algae, the uptake may be dependent upon external as well as internal nutrient concentrations (Rhee, 1973). Adapting this principle to bacterial nutrient uptake, we have chosen simple Monod kinetics for the dependence upon external nutrient concentration and inverse proportionality between uptake velocity and cell quota as given by Equations 5 and 6 (Table 6). No synergistic effects are included in this formulation. Such effects might be expected since uptake of mineral nutrients in bacteria is dependent upon energy obtained through degradation of the organic substrate (Rosenberg et al., 1977).

Since the carbon source is used partly for energy generation, a respiration term removing intracellular carbon in proportion to growth is included (Equation 12a; Table 7). Maintenance requirement is neglected. The effect of increasing $C_{1}$ on the equilibria of this model is shown in Fig. 4 as obtained through solving

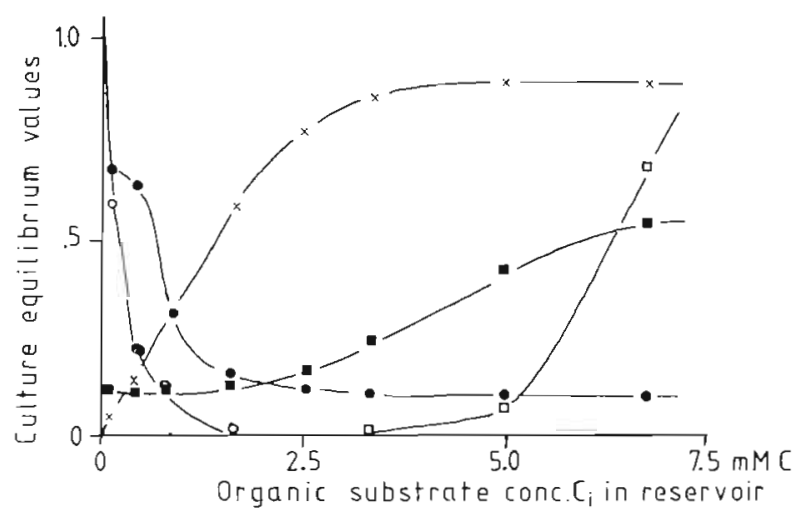

Fig. 4. Droop model, 'bacteria alone'. Simulation results. Effect of increasing $C_{i}$ on culture equilibrium values of $B(x)$, $C(\square), N(O)$ and cell quotas $Q_{B C}(\square)$ and $Q_{B N}(\bullet)$ as obtained from numerical integration at 8 different values of $C_{1}$. Details of simulation given in Tables 1, 2, 5, 6 and 7. Scale mark 1.0 on ordinate equals: $\mathrm{N}: 10 \mu \mathrm{M} \mathrm{PO}_{4}, \mathrm{C}: 1.0 \mathrm{mM} \mathrm{C}, \mathrm{B}: 10^{11} \mathrm{cells}^{1}$,

$Q_{B C}: 100 \mu \mathrm{mol} \mathrm{C}\left(10^{9} \text { cells }\right)^{-1}, Q_{B N}: 1 \mu \mathrm{mol} \mathrm{N}\left(10^{9} \text { cells }\right)^{-1}$

the differential Equations $12 \mathrm{a}$ to $12 \mathrm{~h}$ with $\mathrm{A}=\mathrm{A}_{\mathrm{N}}=\mathrm{P}=\mathrm{O}$ for 8 different values of $C_{r}$. The computation was done using a first order Euler technique on a BBC model B microcomputer. Details of these simulations are found in Tables $1,2,5,6$ and 7 . The major difference between the Monod model (Fig. 3) and the Droop model (Fig. 4) is in the middle region where, due to the storage possibility in bacterial biomass, both mineral and organic substrate may be simultaneously limiting in the Droop model.

\section{SITUATION 2: BACTERIA AND ALGAE}

When both unicellular algae and bacteria are present in the chemostat, we would be particularly interested in how the algal growth affects the degra- 
tion of organic substrate; will the algae grow only on mineral nutrients not used by the bacteria anyway (left region of Fig. 3 and 4), or could there be competition in which the algal consumption of mineral nutrient partially or totally inhibits the bacterial degradation of organic substrate? From another point of view, this is also a question of whether primary production will be outcompeted when there is an input to the system of a substrate for heterotrophic growth. Such effects have been observed in both natural (Parker et al., 1975) and laboratory (Rhee, 1972) systems.

\section{Monod kinetics, with constant yields}

The concentration $N_{A}^{*}$ of limiting mineral substrate in the chemostat at which algal density is at equilibrium, is obtained from Eq. 4 b, Table 4 :

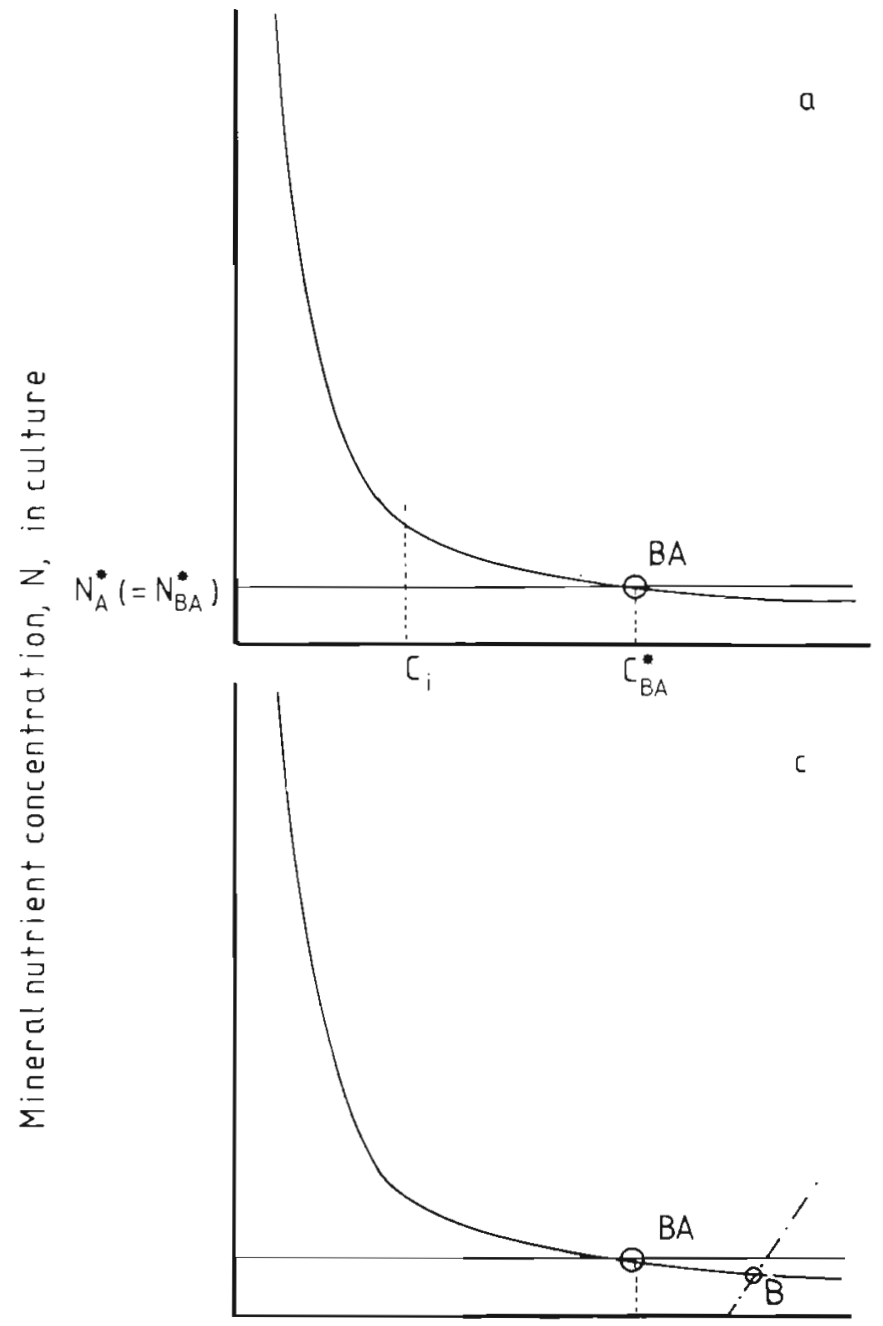

$$
\mu_{\mathrm{A}}\left(\mathrm{N}_{\dot{\mathrm{A}}}\right)=\mathrm{D}
$$

or, when the specific function used for $\mu_{A}$ in Eq. 2, Table 4 is applied:

$$
N_{\dot{A}}^{*}=\frac{D K_{\mathrm{AN}}}{\mu_{\mathrm{A}}^{\operatorname{Max}}-\mathrm{D}}
$$

This corresponds to a line parallel to the C-axis in the $C, N$-plane. The coexistence equilibrium $C_{B_{A}}, N_{\dot{B}_{A}}$ is given as the intersection between this line and the hyperbola obtained from Eq. 13 (which is still valid). Hence, if a coexistence equilibrium exists, $N_{B A}^{*}$ equals $\mathrm{N}_{\mathrm{A}}^{*}$. Note that the hyperbola (Eq. 13) and the line (Eq. 16) are both dependent upon $D$, but independent of $C_{j}$, $N_{i}$. The equilibrium $C_{B_{A}}, N_{B_{A}}$ where bacteria and algae potentially can coexist, is thus dependent upon dilution rate and population parameters, but is independent of reservoir nutrient concentrations $\mathrm{N}_{1}, \mathrm{C}_{\mathrm{i}}$. We will consider 4 different situations:
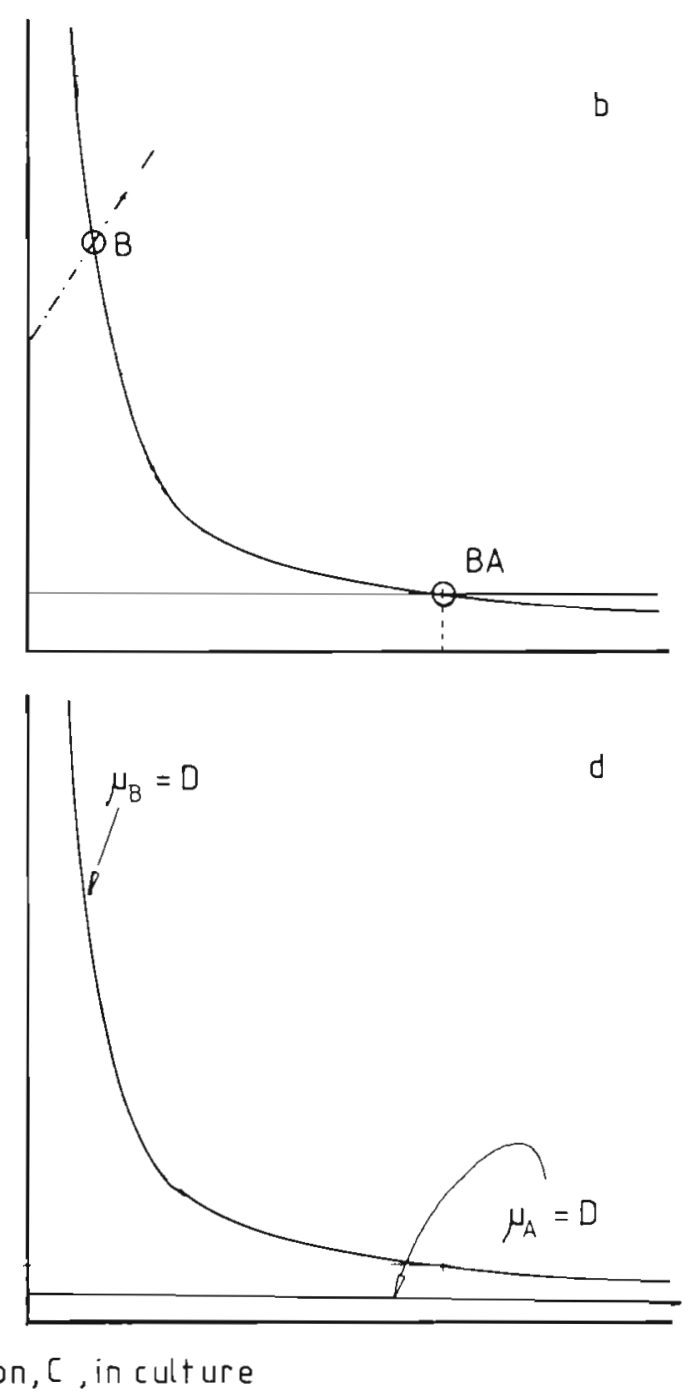

Fig. 5. Monod model, 'bacteria and algae'. Coexistence equilibrium values $C_{B_{A}}, N_{B_{A}}$ obtained at intersection $B A$ between curve $\mu_{B}=D$ and line $\mu_{A}=D$. (a), (b) and (c) correspond to increasing $C_{1}$; (d) corresponds to a situation where the combination of population parameters and dilution rate excludes the possibility for coexistence (see text) 
(1) $C_{i}<C_{B A}^{\cdot}$. Reservoir concentration of organic nutrient is not sufficient to allow a culture concentration high enough for coexistence (Fig. 5a). Bacteria are outcompeted. Culture concentration of $\mathrm{C}$ becomes equal to $C_{1}$ and culture concentration of $N$ is given as $N_{\dot{A}}^{*}$ (Eq. 16.).

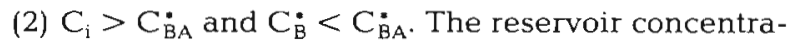
tion of organic nutrient is sufficient to allow coexistence and the position of the equilibrium point B (Fig. $5 b)$ for the 'bacteria alone'-situation is to the left of the coexistence equilibrium BA. Algae and bacteria coexist.

(3) $\mathrm{C}_{\mathrm{B}}>\mathrm{C}_{\mathrm{BA}}^{*}$. The equilibrium point $\mathrm{B}$ (Fig. 5c) for 'bacteria alone' falls to the right and below the coexistence equlibrium BA. The bacteria are able to bring the culture concentration of mineral nutrient below the coexistence value $\mathrm{N}_{B_{A}}$ and the algae are outcompeted.

(4) $N_{A}^{*}<K_{B N} D /\left(\mu_{A}^{\max }-D\right)$. The culture equilibrium value for $\mathrm{N}$ determined by the algae through Equation 16 , is below the horizontal asymptote of the hyperbola (Eq. 13). For the given $D$, no coexistence is possible, not even for large input concentrations $C_{i}$ of organic nutrient (Fig. 5d). The bacteria are outcompeted.

The equilibria corresponding to Situations 1, 2 and 3 above are shown in Fig. 6 for our hypothetical experiment with increasing $\mathrm{C}_{\mathrm{i}}$. The bacteria are unable to

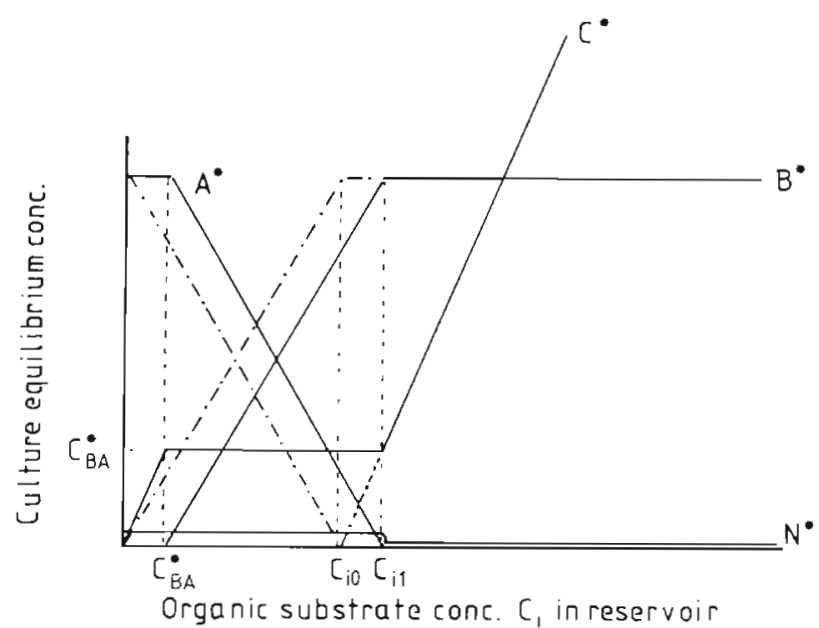

Fig. 6. Monod model, 'bacteria and algae. Effect of increasing $C_{i}$, on culture equilibrium values for bacteria $\left(B^{*}\right)$, algae $\left(A^{*}\right)$, organic substrate $\left(C^{*}\right)$ and mineral nutrient $\left(\mathrm{N}^{*}\right)$. Algal/ bacterial coexistence possible as $C_{i}$ increases beyond $C_{B_{A} i}$ algae outcompeted as $C_{1}$ increases beyond $C_{i 1}$. Dotted lines $(-\cdot)$ indicate bacteria alone situation with transition point $\mathrm{C}_{\mathrm{i} 0}$ from organic to mineral nutrient limitation

compete as long as the input concentration $\mathrm{C}_{1}$ of organic nutrient is below the equilibrium concentration $C_{B} \dot{A}$, allowing coexistence (Fig. 5a). As $C_{1}$ is increased further, bacterial density increases, algal density decreases, while culture concentration of organic nutrient remains at the level $\mathrm{C}_{\mathrm{BA}^{\prime}}$, allowing coexistence. This continues for increasing $C_{i}$ until the point is reached where bacteria will bring the culture concentration of mineral nutrient below the value $\mathrm{N}_{\mathrm{BA}}^{*}$, allowing algal coexistence, and the algae will be outcompeted. Hence, relative to the 'bacteria alone' situation, a complete inhibition of organic substrate degradation occurs in the extreme left part of Fig. 6. Relative to an 'algae alone' situation, the algae are unaffected by an organic input in this region where $\mathrm{C}_{1}<\mathrm{C}_{\mathrm{BA}}$. As $C_{1}$ is increased, a region follows with partial inhibition of organic material degradation as well as a partial inhibition of algal growth, and then, for sufficiently large values of $C_{1}$ there is a region where algae are outcompeted. The situation is then equivalent to the 'bacteria alone' situation, and algae have no effect on degradation of organic material at equilibrium in this region. Whether the algae will be able to maintain themselves in the culture only in the left part of Fig. 6 on mineral nutrient not used by bacteria anyway, or will be able to compete for mineral nutrient further to the right in Fig. 6, depends on whether the straight line is close to or below the horizontal asymptote of the hyperbola shown in Fig. 5a to $5 \mathrm{~d}$. These results represent an extension of the analysis by Gottschal and Thingstad (1982) for competition between autotrophic and heterotrophic bacteria.

\section{Simulation results of a Droop model}

Fig. 7 shows simulation results of a Droop model for bacterial as well as algal growth [Eq. 12a to $12 \mathrm{~h}$, with $\mathrm{P}=\mathrm{O}$; Table (7)]. A specific result for this kind of model is the possibility for algae to compete for mineral nutrients which, in the 'bacteria alone' situation, were stored in bacteria as surplus. Algal growth is then

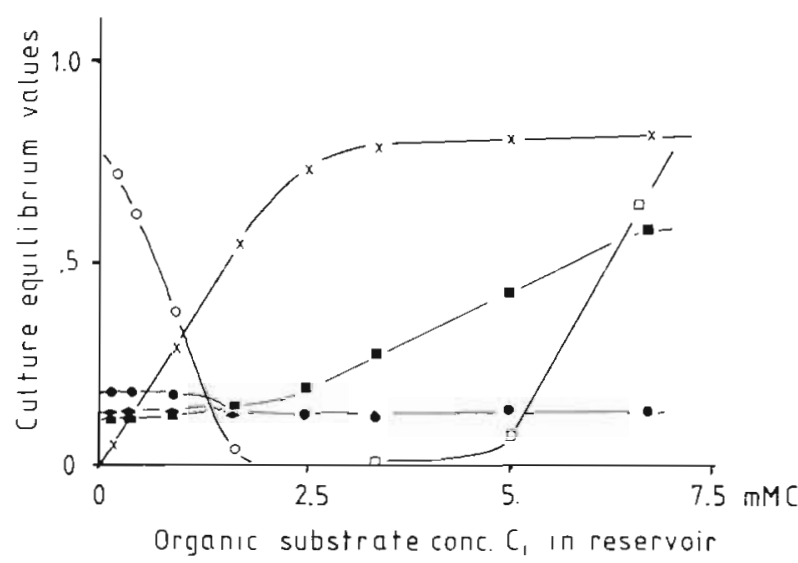

Fig. 7. Droop model, 'bacteria and algae'. Simulation result. Effect of increasing $C_{1}$ on culture equilibrium values $B^{*}(x)$, $\mathrm{A}^{*}(0), C^{*}(\square)$ and cell quotas $Q_{\mathrm{BC}}(\bullet), Q_{\mathrm{BN}}(\bullet)$ and $Q_{\mathrm{AN}}(\bullet)$. Free mineral nutrient concentration small and not shown. Scale mark 1.0 on ordinate equals: A: $10^{9}$ cells $I^{-1}, Q_{\text {AN }}: 1.0$ $\mu \mathrm{mol} \mathrm{PO}_{4}\left(10^{7} \text { cells }\right)^{-1}$, for others as in Fig. 4 
possible in regions where free mineral nutrients are not available in the 'bacteria alone' situation shown in Fig. 3, without any appreciable effects from the algae on equilibrium bacterial density or culture concentration of organic substrate. But the bacterial cell quota $\mathrm{Q}_{\mathrm{BN}}$ of mineral nutrient is then reduced in the region of algal growth.

\section{SITUATION 3: \\ BACTERIA AND BACTIVOROUS PROTOZOA}

The bactivorous protozoans have 2 functions in ow system: (a) they remove bacteria; (b) they remineralize mineral nutrients. Due to this double role, one would expect that, depending on the conditions, predation may lead either to inhibition or to stimulation of the degradation of organic material. The following analysis represents an attempt to identify these conditions.

\section{Monod kinetics and constant yields}

Protozoan predation on bacteria is described in this model by a Monod function (Eq. 3; Table 4). Monod expressions have been used in models compared to experimental systems with various protozoans such as amoebae (Tsuchiya et al., 1972), ciliates (Fenchel, 1980), flagellates (Fenchel, 1982), and by mixed populations in bag experiments (Laake et al., 1983). The growth term of protozoans in Eq. 4c (Table 4) is given as the product of bacteria eaten per time unit, with a yield constant $Y_{\mathrm{PB}}$ of protozoans on bacteria. The term for regeneration of mineral nutrients in Eq. $4 \mathrm{~d}$ (Table 4) is given as the product of an assumed constant amount of mineral nutrient, $\mathrm{r}$, which is regenerated per bacterium eaten, with the number of bacteria eaten per time unit.

In a situation with coexistence of bacteria and protozoans, the equilibrium bacterial density $\mathrm{B}_{\mathrm{BP}}$ must allow a protozoan growth rate equal to the dilution rate (Eq. 4c):

$$
\mathrm{p}\left(\mathrm{B}_{\mathrm{BP}}^{*}\right)=\mathrm{D} / \mathrm{Y}_{\mathrm{PB}}
$$

Or, when the specific functional form of Eq. 3 (Table 4) is chosen:

$$
\mathrm{B}_{\mathrm{BP}}^{*}=\frac{\mathrm{DK}_{\mathrm{PB}}}{\mathrm{Y}_{\mathrm{PB}} \mathrm{p}^{\max }-\mathrm{D}}
$$

Due to the remineralization term, the proportion between mineral and organic nutrient consumed is no longer given by Eq. 14, and due to the predation presure the bacteria must grow faster than the dilution rate (Eq. 13 no longer valid). Rearranging Eq. 4e with $\mathrm{dC} / \mathrm{dt}=\mathrm{O}$ gives:

$$
\mu_{B}(N, C)=D \frac{Y_{B C}\left(C_{1}-C\right)}{B_{B P}^{*}}
$$

The biological background for this equation is that, as $\mathrm{C}_{1}$ is increased, the density of bacterial predators increases. To compensate for the predation pressure, bacteria must, according to Eq. 19, increase their
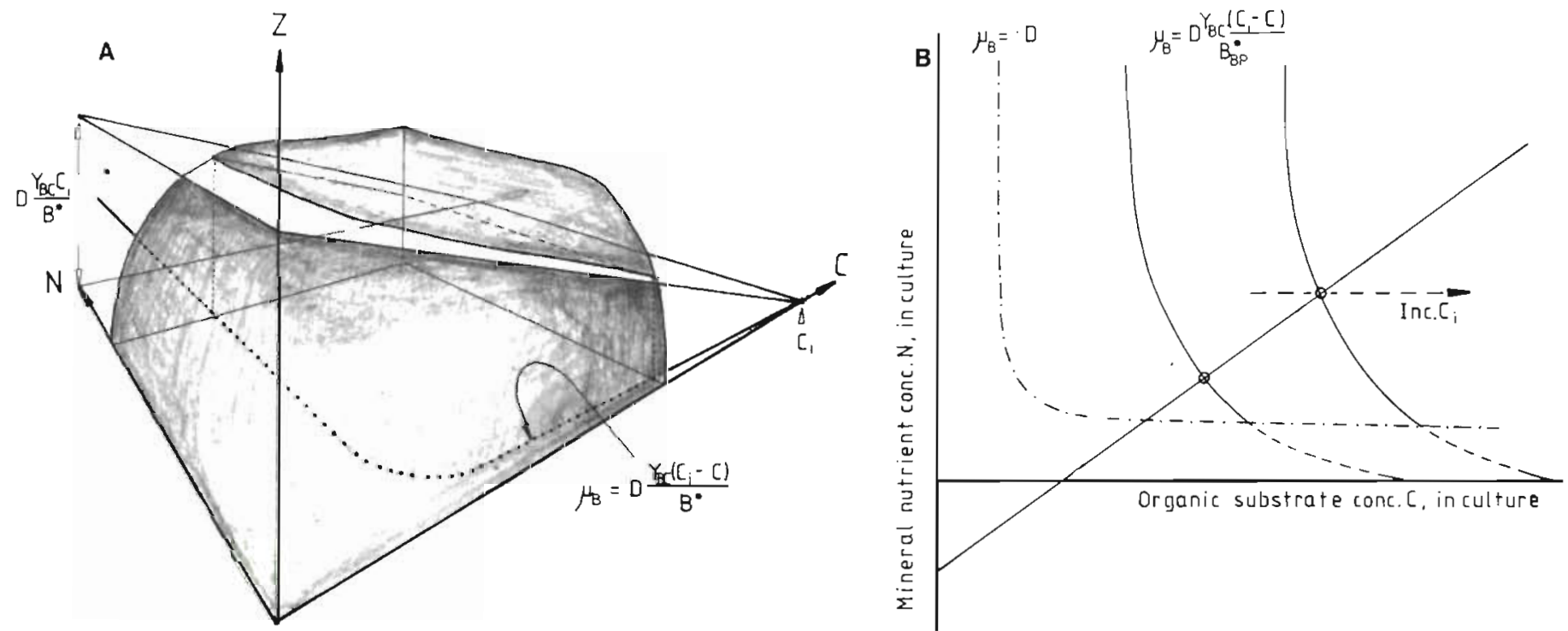

Fig. 8. Monod model, 'bacteria and protozoans'. (A) Visualization of the projection into the C,N-plane of the cut between the $\mathrm{Z}=\mu_{\mathrm{B}}$ surface and the $\mathrm{Z}=\mathrm{DY}_{\mathrm{BC}}\left(\mathrm{C}_{\mathrm{i}}-\mathrm{C}\right) / \mathrm{B}_{\mathrm{B}}$ plane. This projection is a distorted hyperbola' along which bacterial growth rate compensates both for dilution rate and for predation. (B) Coexistence equilibrium values $\mathrm{C}_{\mathrm{BP}}$. $\mathrm{N}_{\mathrm{B} \text { ( }}^{*}$ (marked with circle) obtained at the intersection between 'distorted hyperbola' and line given by Eq.20. Both distorted hyperbola and line move with changing $\mathrm{C}_{1}$. If bacterial growth rate has reached $\mu_{\mathrm{B}}^{\max }$, intersection is on the vertical leg of the distorted hyperbola and the point of equilibrium moves approximately horizontally to the right along broken line as $\mathrm{C}_{1}$ increases 
growth rate above the dilution rate by a factor given as the ratio between the density of bacteria which potentially may be formed on the amount of organic nutrient consumed, and the density of bacteria present in the culture. Since bacterial growth rate is limited upwards

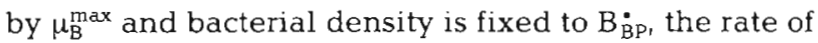
degradation of organic substrate can never exceed $\mathrm{Y}_{\mathrm{BC}}^{-1} / \mu_{\mathrm{B}}{ }^{\max } \mathrm{B}_{\mathrm{BP}}^{*}$

As for Equation 13 in the 'bacteria alone' situation, the solutions to Eq. 19 may be envisaged graphically (Fig. 8a). The left hand side of Eq. 19 describes the same curved surface above the $C_{1} N$-plane as in Fig. 2a. The right hand side, however, is now a plane parallel to the $\mathrm{N}$-axis, but with a negative slope along the $\mathrm{C}$ axis, intersecting the $\mathrm{C}, \mathrm{N}$-plane along the line $\mathrm{C}=\mathrm{C}_{\mathrm{i}}$. As $C_{i}$ increases, the plane described by the right hand side of Eq. 19 moves upwards (Fig. 8a) without change in the slope. The projection of the intersection between the sloped plane and the curved surface into the $\mathrm{C}, \mathrm{N}$ plane gives a 'distorted hyperbola' shown in Fig. $8 \mathrm{~b}$. On all points along such a 'distorted hyperbola', Eq. 19 is fulfilled. Of interest is, however, only the part where bacterial growth rate is greater than the dilution rate, i. e. the part of the 'distorted hyperbola' to the left and above the crossing point with the hyperbola $\mu_{B}=\mathrm{D}$. Relative to Fig. 2 b, the hyperbola will be distorted with the vertical leg moved to the right and with the previously horizontal leg having a negative slope, crossing the $\mathrm{C}$-axis at $\mathrm{C}=\mathrm{C}_{1}$.

The line describing the proportion between nutrients consumed can be obtained combining Eq. $4 \mathrm{a}, \mathrm{d}$, $\mathrm{e}$ (with time differentials zero and $\mathrm{A}=\mathrm{O}$ ). Some rearrangement gives:

$$
\left(N_{i}-N\right)-r_{B P}^{*}=Y_{B C}\left(Y_{B N}^{-1}-r\right)\left(C_{i}-C\right)
$$

Relative to the 'bacteria alone' situation, this is a line in the $\mathrm{C}, \mathrm{N}$-plane where the intersection with the $\mathrm{N}$ axis has moved upwards with an amount $I\left(Y_{B C} C_{1}-B_{B P}^{*}\right)$ and the slope has decreased from $\mathrm{Y}_{\mathrm{BC}} \mathrm{Y}_{\mathrm{BN}}^{-1}$ to $\mathrm{Y}_{\mathrm{BC}}\left(\mathrm{Y}_{\mathrm{BN}}^{-1}-\mathrm{r}\right)$.

In analogy to the 'bacteria alone' situation shown in Fig. 2b, the coexistence equilibrium concentrations of organic and mineral nutrients in the culture is given as the intersection between this line (Eq. 20) and the distorted hyperbola (Eq. 19). As opposed to the previous situations, however, both the line and the distorted hyperbola are dependent upon the reservoir concentration $\mathrm{C}_{i}$ of organic nutrient. Depending on the culture conditions $\left(C_{i}, N_{1}\right.$ and $\left.D\right)$, and the population parameters, the cross between the distorted hyperbola and the line may fall above or below the 'knee' on the distorted hyperbola shown in Fig. 8b. Fig. 9a, b, and c show 3 different possible outcomes of our hypothetical experiment with increasing $C_{i}$. Starting from the left in Fig. $9 a$, a small $C_{1}$, will give bacterial densities smaller than
$\mathrm{B}_{\mathrm{BP}}^{*}$ and protozoans will not be able to maintain themselves in the culture. Mathematically this corresponds to:

$$
\mathrm{Y}_{\mathrm{BC}} \mathrm{C}_{\mathrm{i}}<\mathrm{B}_{\mathrm{BP}}^{*}
$$

or, with a little rearrangement:

$$
C_{i}<Y_{B C}^{-1} \frac{D K_{P R}}{Y_{P B} P^{\max }-D}
$$

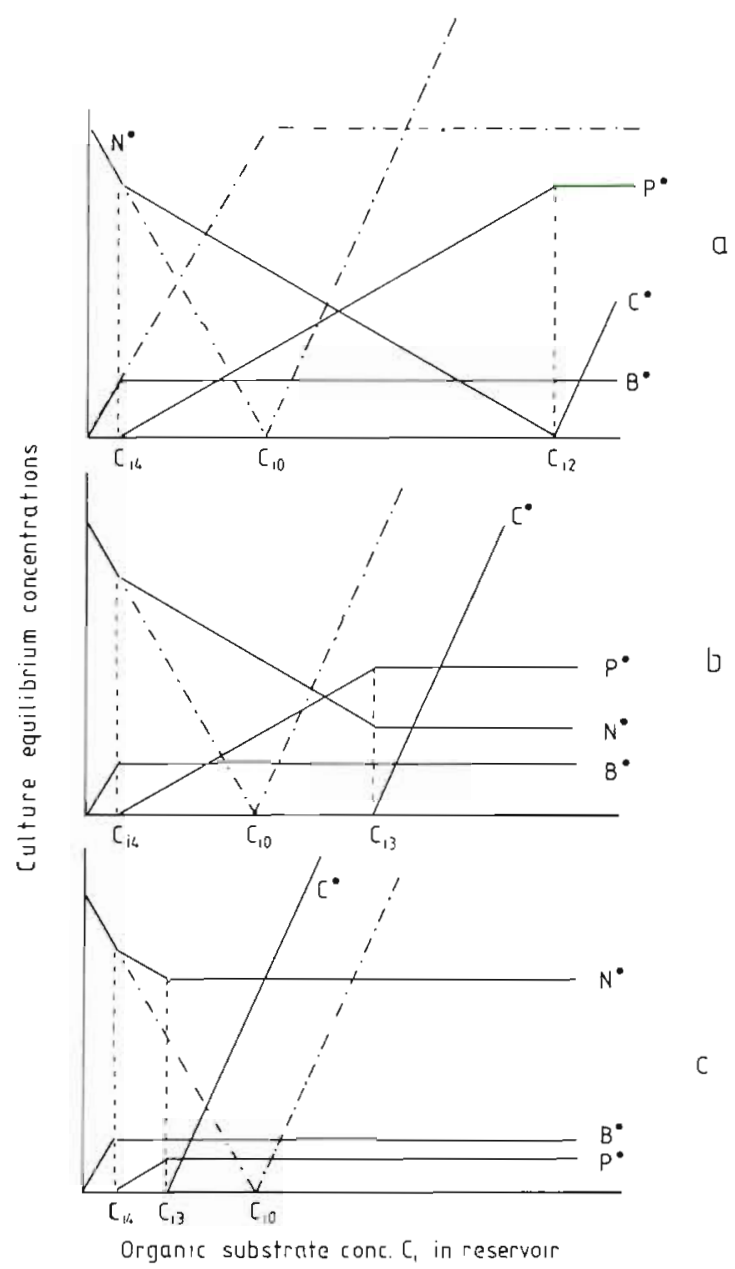

Fig. 9. Monod model, 'bacteria and protozoans'. Effect of increasing $C_{1}$ on culture equilibrium values for bacteria $\left(B^{\circ}\right)$, protozoans $\left(\mathrm{P}^{*}\right)$, organic substrate $\left(\mathrm{C}^{*}\right)$ and mineral nutrient $\left(\mathrm{N}^{*}\right)$. At input concentration $\mathrm{C}_{\mathrm{i}}$, bacterial density is sufficient to allow predator establishment. For increasing $\mathrm{C}_{1}$, bacterial density remains constant and predator density increases until: (a) at $\mathrm{C}_{12}$, input of carbon exceeds the amount which can be used on the input + regenerated mineral nutrient; or (b and c) at $\mathrm{C}_{13}$, the uptake of carbon becomes 'saturated' due to the bacteria growing at their maximum growth rate. Equilibria of 'bacteria alone' situation indicated by dotted lines (- - - . In situations $a$ and $b$, degradation of organic material is stimulated relative to the 'bacteria alone' situation due to regeneration, whereas in situation $c$, characterized by $\mathrm{C}_{\mathrm{i} 3}<\mathrm{C}_{\mathrm{i0}}$, the degradation is partly inhibited due to the effect of removing active bacteria 
Increasing the input concentration $\mathrm{C}_{1}$, of organic material beyond this point will not increase the equilibrium bacterial density, but equilibrium protozoan density starts to increase. The negative slope of the curve for equilibrium culture concentration of mineral nutrient will change at this point due to the remineralization effect of the protozoans. As long as culture concentration of organic nutrient is negligible, Equation 20 reduces to (insertion of $\mathrm{C}=\mathrm{O}$ ):

$$
N_{B P}^{*}=\left(N_{i}-r_{B}^{*}\right)-Y_{B C}\left(Y_{B N}^{-1}-r\right) C_{i}
$$

As more carbon is fed into the system ( $C_{i}$ increases), bacterial growth increases until a limitation occurs, either by $\mu_{\mathrm{B}}$ reaching $\mu_{\mathrm{B}}^{\max }$ or by exhaustion of mineral nutrients.

If the bacteria have a high maximum specific growth rate $\mu_{B}^{\max }$, the vertical leg of the distorted hyperbola in Fig. $8 \mathrm{~b}$ will move to the right only for very large values of $C_{i}$ (seen most easily from Fig. 8a). When this is the case, the intersection between the line and the distorted hyperbola may move to the right of the 'knee' in Fig. $8 \mathrm{~b}$ and the equilibrium culture concentration of mineral nutrient may then become small. In our hypothetical experiment with increasing reservoir concentration $\mathrm{C}_{1}$, this corresponds to the situation shown in Fig. 9a where the line corresponding to $\mathrm{N}_{\mathrm{BP}}^{*}$ extends down to the $C_{i}$-axis. The corresponding value of $C_{1}$ is found from Eq. 23 (inserting $\mathrm{N}_{\mathrm{BP}}=\mathrm{O}$ ):

$$
\mathrm{C}_{\mathrm{i} 2}=\left(\mathrm{N}_{i}-\mathrm{rB}_{\mathrm{BP}}^{*}\right) /\left(\mathrm{Y}_{\mathrm{BC}}\left(\mathrm{Y}_{\mathrm{BN}}^{-1}-\mathrm{r}\right)\right.
$$

Increasing $C_{1}$, beyond $C_{12}$ will give free organic carbon in the culture and no further increase in protozoan density.

If the maximum specific bacterial growth rate $\mu_{B}^{\max }$ has a smaller value, the system will be 'saturated' at a lower input concentration $C_{i}$. This corresponds to the vertical leg of distorted hyperbola (Fig. 8a) starting to move to the right before the line has passed to the right of the 'knee'. Since, in this situation $\mu_{\mathrm{B}} \approx \mu_{\mathrm{B}}^{\max }$ we can combine Eq. 19 and 20 to get:

$$
N_{\mathrm{BP}}^{*} \approx N_{1}-\left(r+\left(Y_{\mathrm{BN}}^{-1}-r\right) \frac{\mu_{\mathrm{B}}^{\max }}{\mathrm{D}}\right) \mathrm{B}_{\mathrm{B} P}^{\cdot}
$$

Equation 25 shows that, as $C_{i}$ is increased, the intersection between the line and the vertical leg of hyperbola now moves along a horizontal path (constant $\mathrm{N}$ ) as indicated by the dotted line in Fig. 8b. The consequence for our hypothetical experiment is shown in Fig. $9 \mathrm{~b}$ and $\mathrm{c}$. From some value $\mathrm{C}_{13}$ of $\mathrm{C}_{1}$, the equilibrium culture concentration of mineral nutrient no longer diminishes, protozoan density becomes constant and concentration of organic substrate in the culture increases. Hence, for $\mathrm{C}_{2}>\mathrm{C}_{\mathrm{i}}$, a situation occurs where there may be measurable concentrations of both $\mathrm{C}$ and $\mathrm{N}$ in the culture, and where bacteria grow at their maximum growth rate.
As can be seen from Fig. $9 \mathrm{~b}$ and $c_{\text {, predation leads to }}$ a stimulation of degradation if $C_{13}>C_{10}$, where $C_{10}$ was the input concentration of organic material corresponding to a shift from limitation on organic to limitation on mineral nutrient in the 'bacteria alone'-situation. The value $C_{i 3}$ where the system gets 'saturated' can be found from Eq. 19 with $\mu_{B}^{*}=\mu_{B}^{\max }$ and $C=0$ :

$$
C_{i 3}=\frac{\mu_{B}^{\max } B_{B P}^{*}}{D Y_{B C}}
$$

\section{Droop model for bacteria combined with protozoan predators}

With a Droop model for bacteria, the composition of the bacterial biomass varies with growth conditions. The amount of mineral nutrient regenerated per bacterium eaten must therefore also vary. The amount of mineral nutrient excreted (which may be zero) is determined from the C:N-ratios of bacteria eaten and predator biomass, and the protozoan C-requirement for respiration. As a simple model, C:N-ratio of predator biomass is assumed constant and a fixed percentage of food carbon is assumed to be used for respiration. In the model it is determined whether carbon or mineral nutrient in the prey is limiting for protozoan growth. Excess mineral nutrient is excreted if protozoan growth is carbon-limited. Details are given in Table 6. Equations $11 \mathrm{a}$ to $11 \mathrm{~h}$. A lower limit of predation is also assumed (Eq. 10a and b; Table 6).

Equilibrium situations obtained by simulation are shown in Fig. 10. Several features not shared with the simple Monod/constant yield-model of Fig. 9a to $\mathrm{c}$ are

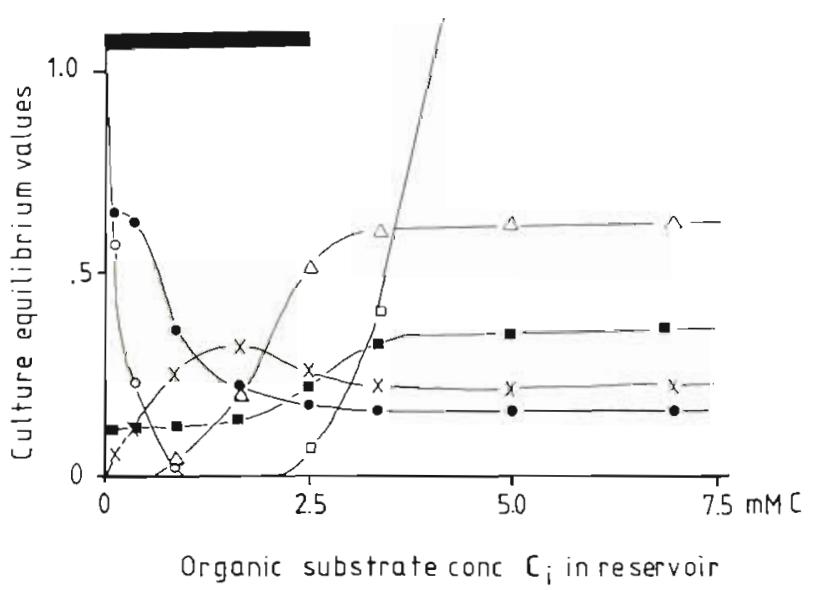

Fig. 10. Droop model, 'bacteria and protozoans'. Simulation results. Effect of increasing $C_{i}$, on culture equilibrium values of $B^{*}(\times), P^{*}(\Delta), C^{*}(\square), N^{*}(0)$ and bacterial cell quotas $Q_{B C}$ $(-)$, and $Q_{B N}(\bullet)$. Black horizontal bar denotes the range of $C_{1}-$ values for which regeneration of mineral nutrient occurs at equilibrium. Scale mark 1.0 on ordinate equals $\mathrm{P}: 10^{9}$ cells $\mathrm{l}^{-1}$, for others see legend to Fig. 4 
revealed in Fig. 10. Unexpected is a region where bacterial density decreases with increasing $C_{r}$. This is due to the varying carbon content $Q_{B C}$ of the bacteria. The equilibrium bacterial density is fixed to the value at which predator growth rate equals the dilution rate. When the ratio $Q_{B C} / Q_{B N}$ between bacterial carbon content and bacterial mineral content is low, the predator growth resulting from ingestion of a bacterium will depend upon $Q_{B C}$. As $Q_{B C}$ increases, predator growth resulting from ingestion of a bacterium increases, and a lower bacterial density is required in order to keep predator density at equilibrium. Another feature of this model is that, as bacterial $\mathrm{C}: \mathrm{N}$-ratio becomes high (right part of Fig. 10), it is the mineral and not the carbon content of the bacteria which limits protozoan growth. Due to this limitation, no regeneration occurs (at equilibrium). This means that the stimulatory effect of predation on degradation of organic material, shown in Fig. 9a and b for the Monod model, may be diminished or vanish with this more complex model. Hunt et al. (1977) presented an analysis of predation using a much more elaborate model of bacterial biomass composition, taking into account carbon, nitrogen and phosphorus content.

With the set of parameters used (Table 5) predatorprey oscillations in the simulations are rapidly dampened. No stability analysis is presented here. An account of the theory of stability analysis in chemostats with predator-prey systems may be found in Cunningham and Nisbet (1983), showing that low dilution rates and the inclusion of a lower limit to predation, as used here, tend to stabilize the systems.

\section{SITUATION 4: \\ BACTERIA, ALGAE AND PROTOZOA}

In this situation, the bacteria are subject to both competition and predation pressures. An interesting question is then whether these 2 pressures interact, i. e. whether predation leads to increased algal growth and to less or more degradation of organic substrate than in the 'bacteria and algae' situation, and whether competition leads to less carbon input into the bacteriaprotozoan pathway than was the case in the 'bacteria and protozoans' situation.

\section{Monod kinetics and constant yields}

Based on the previous analyses of the simpler systems, the general characteristics of this complex situation may be inferred. Fig. 11 is obtained as the combination of the distorted hyperbola of Fig. $8 \mathrm{~b}$ and the horizontal line of Fig. 5. The hyperbola $\mu_{B}=\mathrm{D}$ is also

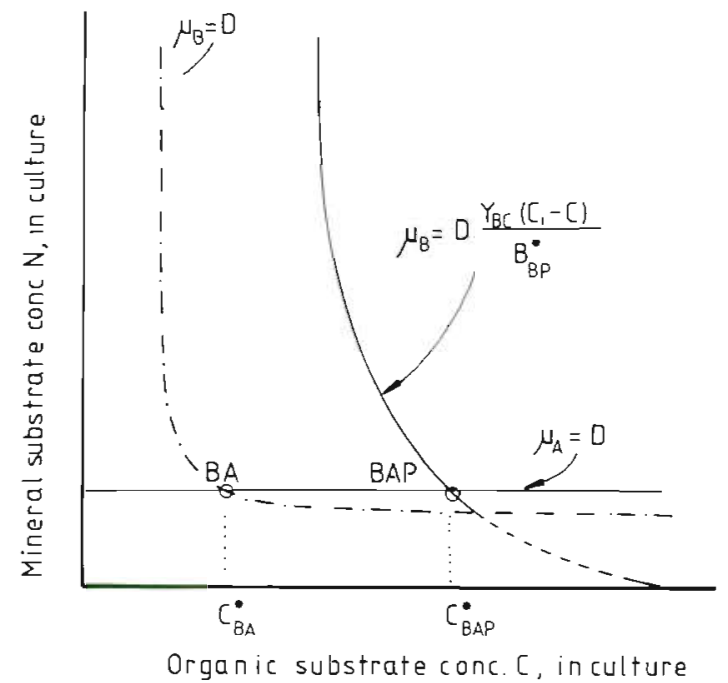

Fig. 11. Monod model, 'bacteria, algae and protozoans'. Coexistence equilibrium values $C_{\text {BAp. }} N_{\text {BAp }}$ obtained as the intersection BAP, between 'distorted hyperbola' along which bacterial growth rate compensates for dilution and predation, and horizontal line along which algal growth rate equals dilution rate. The hyperbola along which bacterial growth rate equals dilution rate indicated by dotted line $(-\cdot-)$

indicated in Fig. 11 to allow a comparison of the equilibria of the 'bacteria and algae' (BA), and 'bacteria, algae and protozoans' (BAP) situations.

With algae present, culture concentration of mineral nutrient is fixed to a value $\mathrm{N}_{\mathrm{BAP}}^{\cdot}\left(=\mathrm{N}_{\mathrm{BA}}^{\cdot}\right)$, represented by the horizontal line in Fig. 11 along which $\mu_{\mathrm{A}}=\mathrm{D}$. If this line approaches the horizontal leg of the hyperbola $\mu_{\mathrm{B}}=\mathrm{D}$, a situation accurs where bacteria can never reach a specific growth rate $\mu_{\mathrm{B}}=\mu_{\mathrm{B}}^{\max }$. Since mineral nutrient concentration in the culture is fixed to $\mathrm{N}_{\mathrm{BAP}}$, the maximum specific growth rate obtainable by the bacterial population will be $\mu_{\mathrm{B}}^{\max } \mathrm{N}_{\mathrm{BAP}}^{*} /\left(\mathrm{K}_{\mathrm{BN}}+\mathrm{N}_{\mathrm{BAP}}^{*}\right)$. Due to this effect, the bacterial growth will become 'saturated' at a lower density of predators, i. e. at a lower input concentration $C_{1}$ of organic substrate in the reservoir. Some of the main effects of increasing organic input concentration $C_{1}$ are demonstrated in Fig. 12. For small $\mathrm{C}_{1}\left(<\mathrm{C}_{\mathrm{B}_{\mathrm{A}}}\right)$, bacteria are outcompeted and only algae will establish thenselves in the system. Increasing $\mathrm{C}_{\mathrm{i}}$ beyond $\mathrm{C}_{\mathrm{BA}}$ leads to increasing bacterial density, but protozoans are unable to establish themselves until bacterial density reaches $B_{B P}\left(=B_{B A P}\right)$ at $C_{i}=C_{i 5}$. Note that, due to the competition from algae, this bacterial density is reached at a greater value of $C_{1}$ than was the case in the 'bacteria and protozoans' situation $\left(C_{i 4}\right.$; Fig. 9). As protozoans are established, remineralization takes place, reducing the slope of the decline in algal population with increasing $\mathrm{C}_{\mathrm{i}}$. Predation pressure on the bacteria thus leads to an increase in algal density relative to the 'bacteria and algae' situation. If the bacterial growth rate becomes 'satu- 


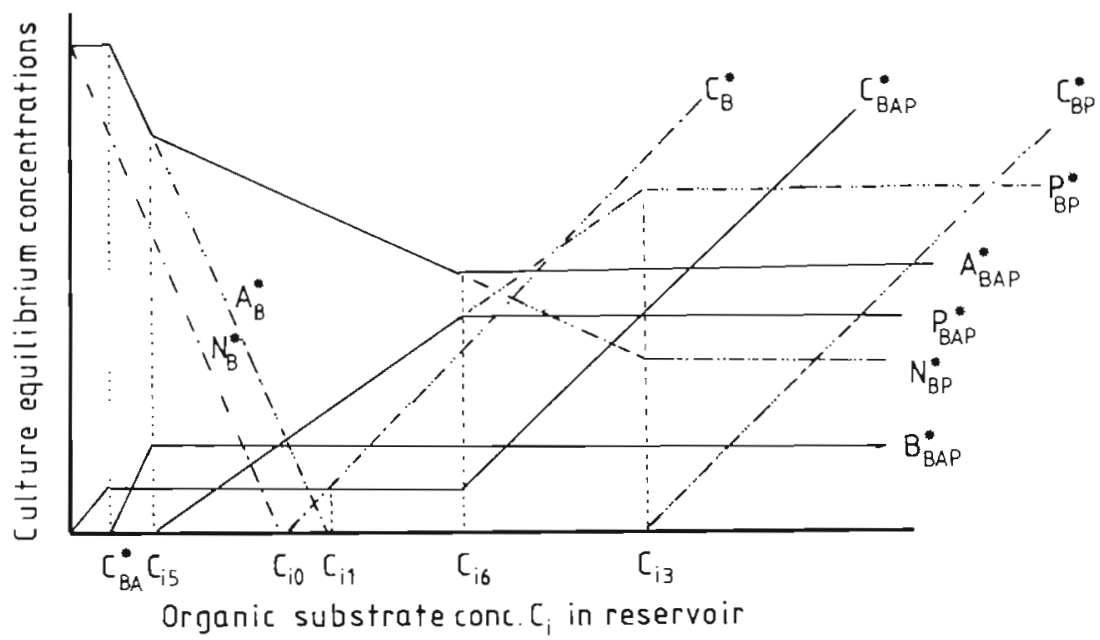

Fig. 12. Monod model, 'bacteria, algae and protozoans'. Effect of increasing $C_{i}$ on culture equilibrium values of bacteria $\left(B_{B A P}\right)$, protozoans $\left(\mathrm{P}_{\mathrm{BAP}}\right)$, algae $\left(\mathrm{A}_{\mathrm{BAP}}\right)$ and organic substrate $\left(\mathrm{C}_{\mathrm{BAP}}\right)$. Equilibrium values for the other situations are indicated by $(-\cdot-)$ for 'bacteria alone', with (-.-) for 'bacteria and algae', and with (-...-) for 'bacteria and protozoans'. At $C_{i s}$, bacterial density is sufficient to allow establishment of protozoans, at $\mathrm{C}_{16}$, bacterial growth rate reaches its saturation level. Indicated are also the positions $C_{10}$ where transition from organic to mineral nutrient limitation occurs in the 'bacteria alone' situation, $C_{11}$ where algae are outcompeted in the 'bacteria and algae' situation, and $C_{13}$ where bacterial growth rate reaches its saturation level in the 'bacteria and protozoans' situation

rated' before algal density becomes zero, algae will maintain themselves in the chemostat for all values of $C_{i}$. As explained above, this 'saturation' occurs at a smaller $C_{i}\left(=C_{i 6}\right.$. Fig. 12) than was the case in the 'bacteria and protozoans' situation. The consequences of this may be seen in Fig. 12. In region for $C_{1}>C_{16}$ competition algae/bacteria leads to reduced protozoan density relative to the 'bacteria and protozoans' situation. In region for $C_{1}>C_{i 5}$, predation pressure on bacteria leads to increased algal density relative to the 'bacteria and algae' situation. In the 'bacteria, algae and protozoans' situation, competition leads to a partial inhibition of organic material degradation relative to the 'bacteria and protozoans' situation. Predation, on the other hand, may either stimulate or partly inhibit organic material degradation relative to the 'bacteria and algae' situation, depending upon the position of $\mathrm{C}_{16}$ relative to $\mathrm{C}_{11}$.

\section{Droop model: algae, bacteria and protozoans together}

Fig. 13 shows the equilibrium concentrations and population densities of the simulation model for increasing values of $C_{i j}$, when all 3 populations are present. The curves are largely in agreement with the analysis of the more simple Monod model above. Due to predation on the bacteria, algae may maintain themselves in the chemostat at all values of organic input $\mathrm{C}_{\mathrm{i}}$. Due to competition between algae and bacteria for mineral nutrient, the protozoan density is reduced relative to the 'bacteria and protozoans' situation of Fig. 10 .
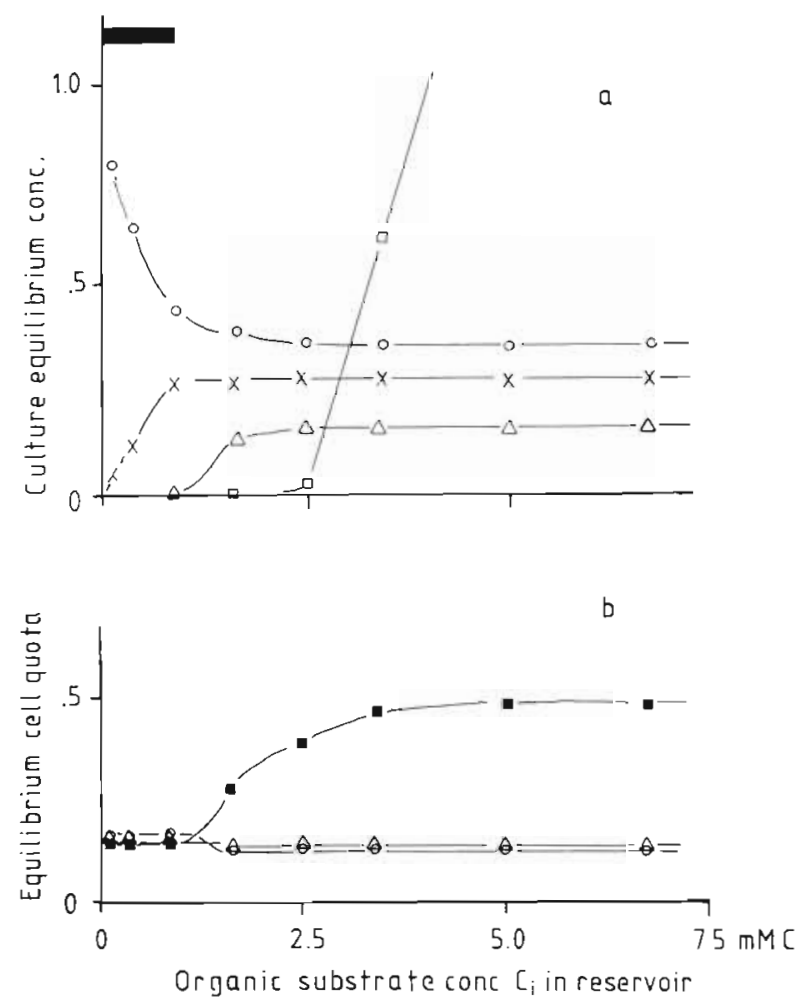

Fig. 13. Droop model, 'bacteria, algae and protozoans'. Simulation results. Effect of increasing $C_{i}$ on the culture equilibrium values of: (a) bacteria $(x)$, algae $(0)$, protozoans $(\Delta)$ and organic substrate $(\square)$; black horizontal bar denotes the range of $\mathrm{C}_{\mathrm{i}}$-values for which regeneration of mineral nutrients occurs at equilibrium; (b) bacterial cell quotas $Q_{B C}(\boldsymbol{D})$ and $Q_{B N}(O)$ and algal cell quota $Q_{A N}(\Delta)$. Ordinate scale as in Fig. 4,7 and 10 
Due to the competition for $\mathrm{N}$, the storage of $\mathrm{N}$ in bacteria for small values of $C_{i}$ (seen in Fig. 4 and 10) has disappeared. This again leads to limitation of protozoans by the mineral content in the bacterial prey at a smaller value of $C_{1}$, than in the situation without algae (Fig. 10).

\section{NON-INTERACTIVE BACTERIAL GROWTH}

The form of the $\mu_{B}(N, C)$-function determines the contours corresponding to $\mu_{\mathrm{B}}=\mathrm{D}$ and $\mu_{\mathrm{B}}=$ $D Y_{B C}\left(C_{i}-C\right) / B_{B P}^{*}$ in the $C, N$-plane (Fig. 8b). As seen from the previous analyses, these contours are crucial for the outcome of the competition and predation situations. So far, both substrates have been assumed to potentially influence the bacterial growth simultaneously. As pointed out by Bader et al. (1975) and Bader (1978), an alternative approach is to assume that one substrate only can influence the growth at one time. For the Monod model this corresponds to:

$\mu_{B}=\mu_{B}^{\max } \frac{C}{K_{B C}+C}$ for $C / K_{B C}<N / K_{B N}$
$\mu_{B}=\mu_{B}^{\max } \frac{N}{K_{B N}+N}$ for $N / K_{B N}<C / K_{B C}$

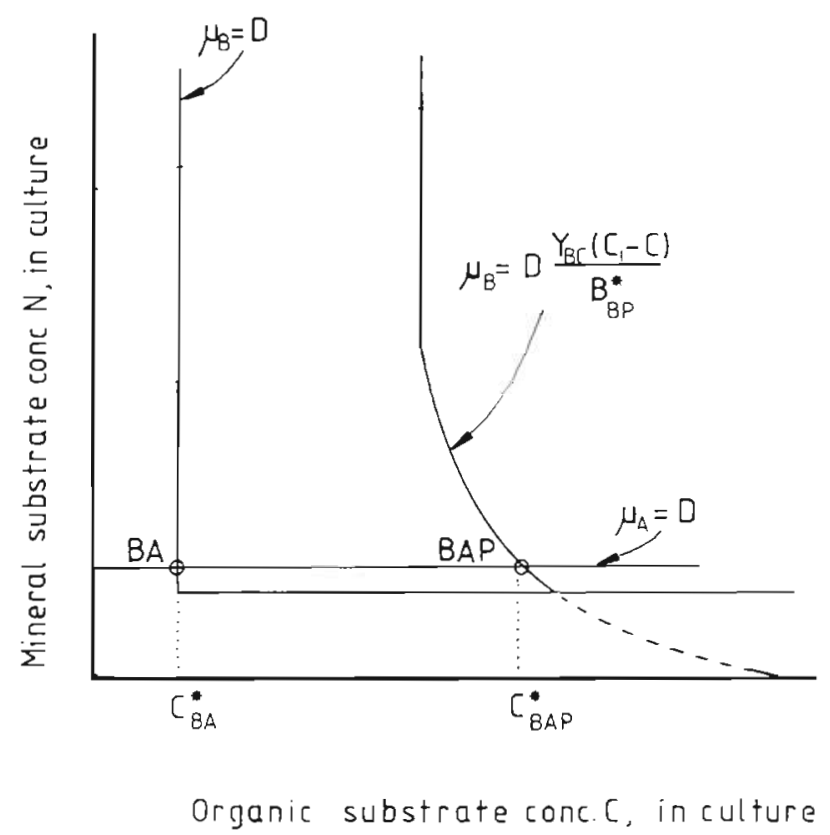

Fig. 14. Monod model; non-interactive bacterial growth. Position of coexistence equilibria BA and BAP when bacterial growth on the carbon and mineral nutrient is assumed to be non-interactive. BAP will always be to the right, i. e. have greater $\mathrm{C}$-values than $\mathrm{BA}$. When bacterial growth is carbonlimited, the 'bacteria alone' equilibrium will be on the vertical leg of the $\mu_{\mathrm{B}}=\mathrm{D}$-curve and organic substrate concentration in the culture will be the same in the 'bacteria alone' and in the 'bacteria and algae' situation
Fig. 14 gives the contours of this function and the curve corresponding to the previous 'distorted hyperbola' of the situations with predation. The main consequence of the non-interactive model is to transform the previous hyperbola into two straight lines meeting at a right angle. The effect on the 'distorted hyperbola' will be less pronounced, the vertical leg will be a straight line, and a discontinuity will occur in the slope of the curve as the line $C / K_{B C}=N / K_{B N}$ is passed. One consequence of this non-interactive model is in the competition situation between algae and bacteria. Coexistence equilibrium concentration $C_{B_{A}}^{*}$ of organic substrate now (if it exists) coincides with the culture concentration of organic substrate in the 'bacteria alone' situation (Fig. 14). In the 'bacteria and algae' situation, algae will either grow on mineral nutrients not used by bacteria in the 'bacteria alone' situation and the competition will have no effect on the bacterial degradation of organic substrate, or, as in the case analogous to the one shown in Fig. 5d, the bacteria will be outcompeted irrespective of organic input concentration. A similar effect would be expected from inclusion of noninteractive growth in the Droop model, although this has not been investigated further.

\section{DISCUSSION}

The analysis presented here is an attempt to simplify the 'microbial loop' and its physical/chemical environment to a stage where the effects of environmental conditions (D, $C_{i}$ and $N_{1}$ ) and population properties $(\mu, K, p, r, Y$-values) may be analyzed theoretically.

The analysis has demonstrated how the interaction works both ways: The degradation of organic matter is influenced by the mechanisms of the ecological system and the addition of organic matter will influence the structure and function of the biological community.

Some of the conditions regulating the outcome of the competition between algae and bacteria have been analyzed, as well as some of the conditions determining whether predation on the bacterial population would be expected to stimulate or inhibit dégradation. The model also demonstrates how competition and predation may interact to give an additional negative effect on degradation and also how predation on the bacteria may relieve part of the competition pressure on algae.

Due to its amenability to graphical analysis, the simple 'Monod model with constant yields' proved indispensable for the exploration of main features of this system. The numerical analysis of the slightly more elaborated Droop model demonstrates, however, how important aspects may be added if models with 
more flexible physiological properties of the organisms are applied.

A multitude of relevant, but complicating, biological effects are not accounted for here. An example would be a stimulatory effect of carbon source on mineral nutrient uptake or the existence of multiple uptake systems for the limiting substrates (e.g. Rosenberg et al., 1977; Höfle, 1982). In natural communities one would also expect different conditions to select for different algal, bacterial and protozoan populations. This would add to the flexibility of the system and more complicated models would probably be required.

In the analysis presented, the bacterial growth response at low concentrations of 2 limiting substrates is of central importance. Though much work on dual substrate limitation of bacteria (Dijkhuizen and Harder, 1979; Gottschal and Kuenen, 1980) and yeasts (Egli et al., 1982a, b) have been published recently, this has mainly concerned the problems of autotrophic versus heterotrophic growth, and the consumption of 2 substitutable carbon or energy sources. The results are therefore not directly applicable to the present situation where the 2 potentially limiting substrates both are assumed to be required for bacterial growth.

Experimental systems of the kind analyzed, continuous cultures of gnotobiotic cultures, may be constructed in the laboratory. Results of the analysis presented here should be directly applicable both in planning and interpretation of such experiments.

Acknowledgements. We thank Professor lan Dundas for ideas and support and Dr. Hein Rune Skjoldal for careful reading and constructive criticism of the manuscript.

This work was financed partly by the Norwegian Marine Pullution Research and Monitoring Programme (FOH), and partly by the Norwegian Program for Marine Arctic Ecology (PROMARE).

\section{LITERATURE CITED}

Atlas, R. M. (1981). Microbial degradation of petroleum hydrocabons: an environmental perspective. Microbiol. Rev. 45: $180-209$

Azam, F., Fenchel, T., Field, J. G., Gray, J. S., Meyer-Reil, L. S., Thingstad, F. (1983). The ecological role of watercolumn microbes in the sea. Mar. Ecol. Prog. Ser. 10: 257-263

Bader, F. G. (1978). Analysis of double-substrate limited growth. Biotechnol. Bioeng. 20: 181-202

Bader, F. G., Meyer, J. S., Frederickson, A. G., Tsuchiya, H. M. (1975). Comments on microbial growth rate. Biotechnol. Bioeng. 17: 279-283

Brown, E. J., Button, D. K., Lang, D. S. (1981). Competition between heterotrophic and autotrophic microplankton for dissolved nutrients. Microb. Ecol. 7: 199-206

Cunningham, A., Nisbet, R. M. (1983). Transients and oscillations in continuous culture. In: Bazin, M. (ed.) Mathematics in microbiology. Academic Press, New York, p. $77-103$
Dawes, E. A., Senior, P. J. (1973). The role and regulation of energy reserve polymers in micro-organisms. In: Rose, A. H., Tempest, D. W. (ed.) Adv. microb. Physiol. 10: 135-266

Dijkhuizen, L., Harder, W. (1979). Regulation of autotrophic and heterotrophic growth metabolism in Pseudomonas oxalaticus 0X1. Growth on mixtures of acetate and formate in continuous culture. Arch. Microbiol. 123: 47-53

Droop, M. R. (1974). The nutrient status of algal cells in continuous culture. J. mar biol. Ass. U. K. 54: 825-855

Egli, T., Käppeli، O., Fiechter, A. (1982a). Regulatory flexibility of methylotrophic yeasts in chemostat cultures: simultaneous assimilation of glucose and methanol at a fixed dilution rate. Arch. Microbiol. 131: 1-7

Egli, T., Käppeli, O., Fiechter, A. (1982b). Mixed substrate growth of methylotrophic yeasts in chemostat culture: influence of the dilution rate on the utilization of a mixture of glucose and methanol. Arch. Microbiol. 131: 8-13

Fenchel, T. (1980). Suspension feeding in ciliated protozoa: functional response and particle size selection. Microb. Ecol. 6: 1-11

Fenchel, T. (1982). Ecology of heterotrophic microflagellates. II. Bioenergetics and growth. Mar. Ecol. Prog. Ser. 8: 225-231

Fenchel, T, Blackburn, T. H. (1979). Bacteria and mineral cycling. Academic Press, New York

Gottschal, J. C., Kuenen, J. G. (1980). Mixotrophic growth of Thiobacillum $\mathrm{A} 2$ on acetate and thiosulphate as growth limiting substrates in the chemostat. Arch. Microbiol. 126: $33-42$

Gottschal, J. C., Thingstad, T F. (1982). Mathematical description of competition between two and three bacterial species under dual substrate limitation in the chemostat. Biotechnol. Bioeng. 24: 1403-1418

Herbert, D., Elsworth, R., Telling, R. C. (1956). The continuous culture of bacteria; a theoretical and experimental study. J. gen. Microbiol. 14: 601-622

Hunt, H. W., Cole, C. V., Klein, D. A., Coleman, D. C. (1977). A simulation model for the effect of predation on bacteria in continuous culture. Microbiol Ecol. 3: 259-278

Höfle, M. G. (1982). Glukose uptake in Cytophage johnsonae studied in batch and chemostat culture. Arch. Microbiol. 133: 289-294

Johannes, R. E. (1968). Nutrient regeneration in lakes and oceans. In: Droop, M. R., Ferguson, E. J. (ed.) Adv. microb. Sea 1: 203-213

Laake, M., Dahle, A. B., Eberlein, K., Rein, K. (1983). A modelling approach to the interplay of carbohydrates, bacteria and non-pigmented flagellates in a controlled Ecosystem experiment with Skeletonema costatum. Mar Ecol. Prog. Ser. 14: 71-79

Mann, H. H. (1982). Ecology of coastal waters: a systems approach. Blackwell Scientific Publications.

Megee, R. D., Drake, J. F., Frederickson, A. G., Tsuchiya, H. M. (1972). Studies in intermicrobial symbiosis. Can. J. Microbiol. 18: 1733-1742

Monod, J. (1942). Recherches sur la croissance des cultures bacteriennes. Hermann et Cie, Paris

Nyholm, N. (1976). A mathematical model for microbial growth under limitation by conservative substrates. Biotechnol. Bioeng. 18: 1043-1056

Parker, R. R., Sibert, J., Brown, T J. (1975). Inhibition of primary productivity through heterotrophic competition for nitrate in a stratified estuary. J. Fish. Res. Bd Can. 32: $72-77$

Pirt, S. J. (1982). Maintenance energy: a general model for energy-limited and energy-sufficient growth. Arch. Microbiol. 133: 300-302 
Rhee, G.-Y. (1972). Competition between an alga and an aquatic bacterium for phosphate. Limnol. Oceanogr. 17: 505-514

Rhee, G.-Y. (1973). A continuous culture study of phosphate uptake, growth rate and polyphosphate in Scenedesmus sp. J. Phycol. 9: 495-506

Rhee, G.-Y. (1980). Continuous culture in phytoplankton ecology. In: Droop, M. R., Jannasch, H. W. (ed.) Advances in aquatic microbiology, Vol. 2. Academic Press, New York, p. 151-203

Rosenberg, H., Gerdes, R. G., Chegwidden, K. (1977). Two systems for the uptake of phosphate in Escherichia coli. J Bacteriol. 131: 505-511

Tsuchiya, H. M., Drake, J. F., Jost, J. L., Fredrickson, A. G (1972). Predator-prey interactions of Dictyostelium discoideum and Escherichia coli in continuous culture. J. Bacteriol. 110: 1147-1153

Tempest, D. W., Dicks, J. W., Hunter, J. R. (1966). The interrelationship between potassium, magnesium and phosphorus in potassium limited chemostat cultures of Aerobacter aerogenes. J. gen. Microbiology 45: 135-146

This paper was presented by Dr. H. R. Skjoldal; it was accepted for printing on September 28, 1984 